\title{
Atmospheric methane and global change
}

\author{
Donald J. Wuebbles*, Katharine Hayhoe \\ Department of Atmospheric Sciences, University of Illinois, Urbana, IL 61801, USA
}

Received 21 March 2000; accepted 4 April 2001

\begin{abstract}
Methane $\left(\mathrm{CH}_{4}\right)$ is the most abundant organic trace gas in the atmosphere. In the distant past, variations in natural sources of methane were responsible for trends in atmospheric methane levels recorded in ice cores. Since the 1700s, rapidly growing human activities, particularly in the areas of agriculture, fossil fuel use, and waste disposal, have more than doubled methane emissions. Atmospheric methane concentrations have increased by a factor of $2-3$ in response to this increase, and continue to rise. These increasing concentrations have raised concern due to their potential effects on atmospheric chemistry and climate. Methane is important to both tropospheric and stratospheric chemistry, significantly affecting levels of ozone, water vapor, the hydroxyl radical, and numerous other compounds. In addition, methane is currently the second most important greenhouse gas emitted from human activities. On a per molecule basis, it is much more effective a greenhouse gas than additional $\mathrm{CO}_{2}$. In this review, we examine past trends in the concentration of methane in the atmosphere, the sources and sinks that determine its growth rate, and the factors that will affect its growth rate in the future. We also present current understanding of the effects of methane on atmospheric chemistry, and examine the direct and indirect impacts of atmospheric methane on climate. (C) 2002 Elsevier Science B.V. All rights reserved.
\end{abstract}

Keywords: methane; greenhouse gases; atmospheric chemistry; global change

\section{Introduction}

Methane $\left(\mathrm{CH}_{4}\right)$ is the most abundant organic trace gas in the atmosphere. Concentrations ${ }^{1}$ of $\mathrm{CH}_{4}$ have more than doubled since pre-industrial times, with a current globally-averaged mixing ratio of $\sim 1750$ $\mathrm{ppbv}^{2}$ (NOAA CMDL data, Dlugokencky, personal communication). The effects of $\mathrm{CH}_{4}$ on climate and

\footnotetext{
${ }^{*}$ Corresponding author. Tel.: +1-217-244-1568; fax: +1-217244-4393.

E-mail address: wuebbles@atmos.uiuc.edu (D.J. Wuebbles).

${ }^{1}$ Concentration for methane as used here is actually volume mixing ratio (or mole fraction).

${ }^{2}$ ppbv $=$ Parts per billion $\left(10^{9}\right)$ by volume.
}

atmospheric chemistry are the reason for concern over its high growth rate. Following water vapor and carbon dioxide $\left(\mathrm{CO}_{2}\right)$, methane is the most abundant greenhouse gas in the troposphere. Both on a molecule and a mass basis, additional methane is actually much more effective as a greenhouse gas than additional $\mathrm{CO}_{2}$. Methane is also the most abundant reactive trace gas in the troposphere and its reactivity is important to both tropospheric and stratospheric chemistry. The oxidation of $\mathrm{CH}_{4}$ by hydroxyl $(\mathrm{OH})$ in the troposphere leads to the formation of formaldehyde $\left(\mathrm{CH}_{2} \mathrm{O}\right)$, carbon monoxide $(\mathrm{CO})$, and ozone $\left(\mathrm{O}_{3}\right)$, in the presence of sufficiently high levels of nitrogen oxides $\left(\mathrm{NO}_{x}\right)$. Along with $\mathrm{CO}$, methane helps control the amount of $\mathrm{OH}$ in the troposphere. Methane also 
affects the concentrations of water vapor and ozone in the stratosphere, and plays a key role in the conversion of reactive chlorine to less reactive $\mathrm{HCl}$ in the stratosphere.

The purpose of this paper is to examine the past trends in the concentration of methane, the sources and sinks affecting its growth rate, and the factors that could affect its future growth rate. This study also examines the current understanding of the effects of methane on atmospheric chemistry and on climate.

\section{Record and budget of atmospheric $\mathrm{CH}_{4}$}

\subsection{Distribution and trend}

\subsubsection{Atmospheric $\mathrm{CH}_{4}$ in the distant past}

Air bubbles trapped in polar ice provide a continuous record of the atmospheric concentration of methane (e.g., Legrand et al., 1988; Chappellaz et al., 1990; Etheridge et al., 1992, 1998; Jouzel et al., 1993; Nakazawa et al., 1993; Raynaud et al., 1993; Blunier et al., 1995, 1998; Brook et al., 1996). Ice cores from Greenland and Antarctica now extend the record of atmospheric $\mathrm{CH}_{4}, \mathrm{CO}_{2}$ and temperature back to 420,000 years BP (Petit et al., 1999), covering four glacial-interglacial cycles.

The record shown in Fig. 1 reveals two important characteristics of past $\mathrm{CH}_{4}$ concentrations with implications for future climate. First, present-day $\mathrm{CH}_{4}$ levels appear to be unprecedented during any time in the past. Ice core records show glacial-interglacial transitions rising from $320-350 \mathrm{ppbv}$ up to a maximum of 650-780 ppbv (Petit et al., 1999), corresponding to source increases as large as 50-60 $\mathrm{TgCH}_{4} /$ year (Brook et al., 1996, based on Chappellaz et al., 1993a). This is less than half of present-day concentrations, which are currently greater than 1700 ppbv. Secondly, $\mathrm{CH}_{4}$ is closely tied to atmospheric temperature records, decreasing and rising in phase with temperature at the inception and termination of glacial episodes (e.g., Petit et al., 1999; Chappellaz et al., 1993a,b; Raynaud et al., 1988).

The observed synchronicity between temperature and $\mathrm{CH}_{4}$ concentrations has raised the question of the role of $\mathrm{CH}_{4}$ in glacial-interglacial climate change. Do increasing $\mathrm{CH}_{4}$ emissions actually help initiate climate change, or do they respond quickly to rising

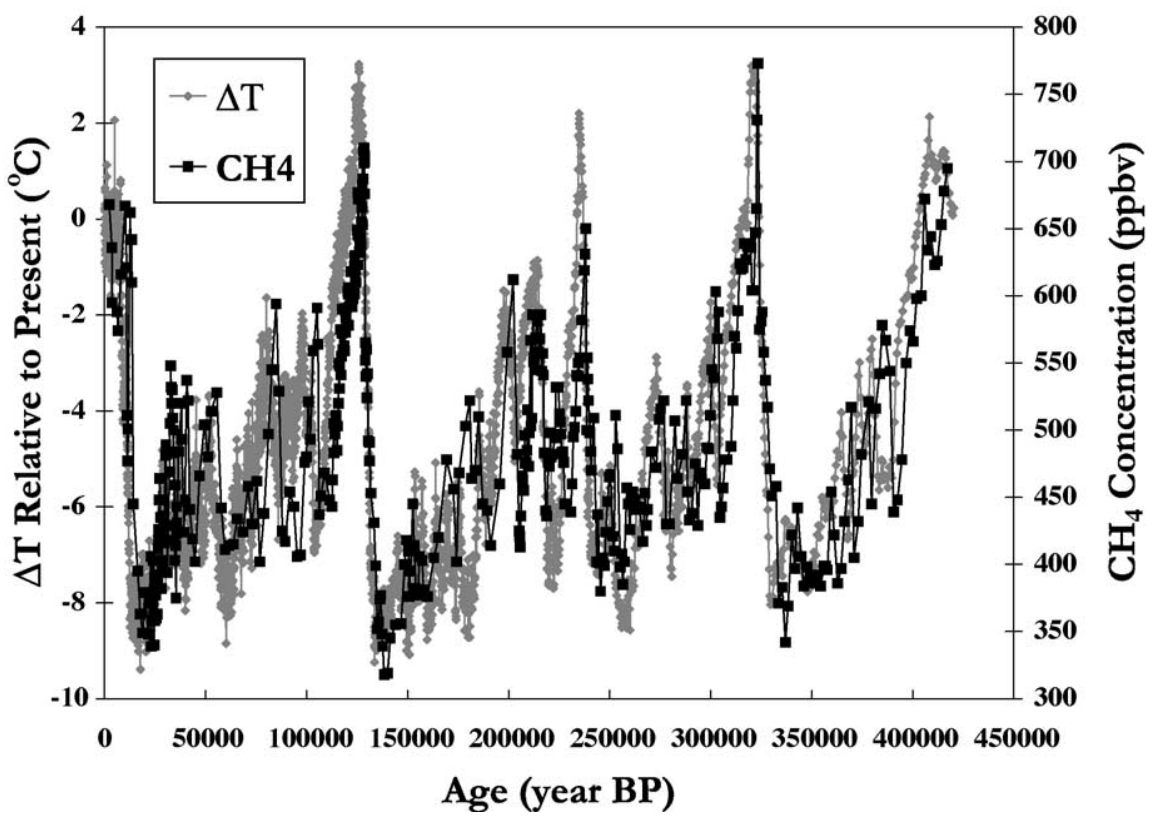

Fig. 1. Vostok ice core records of atmospheric temperature and methane concentration (volume mixing ratio) from 420,000 years BP to present (source: Petit et al., 1999). 
atmospheric temperatures? Theories of $\mathrm{CH}_{4}$ as an instigator of glacial terminations point to the potential destabilization of methane clathrates contained in sediments on continental shelves, as sea level fell due to growing ice sheets. This destabilization could have led to abrupt large-scale releases of $\mathrm{CH}_{4}$ into the atmosphere, capable of inducing a global temperature increase of up to $1-2^{\circ} \mathrm{C}$ over a few decades (Dickens et al., 1997; Thorpe et al., 1996). Such a hypothesis has been shown to be consistent with the geological record of observed perturbations in carbon isotopes (Dickens et al., 1997; Bains et al., 1999), and is not inconsistent with the absence of an observed spike in $\mathrm{CH}_{4}$ concentrations from ice cores with a 300 -year sampling interval ${ }^{3}$ (Thorpe et al., 1996). However, results from several ice core studies support the hypothesis that increased emissions from low-latitude, followed by higher latitude, wetlands in response to climate change were responsible for the majority of $\mathrm{CH}_{4}$ increases (Chappellaz et al., 1993a,b; Thompson et al., 1993; Blunier et al., 1995; Brook et al., 1996). The importance of wetland emissions is emphasized by an observed drop in $\mathrm{CH}_{4}$ concentrations during the mid-Holocene, when tropical lakes may have dried (Blunier et al., 1995), and interactions between climatic influences and ecosystem dynamics would have reduced wetland emissions (Velichko et al., 1998). A recent modeling study (Dällenbach et al., 2000) also finds large changes in northern latitude sources during warm Dansgaard/Oeschger events during the last glacial period.

An innovative method for extracting temperature data from ice cores has recently shown that $\mathrm{CH}_{4}$ increases at the end of the Younger Dryas cold period began somewhere between 0 and 30 years following an abrupt temperature increase (Severinghaus et al., 1998). A successive study of four rapid climate transitions over the past 50,000 years reveals that following each transition, temperature increased more rapidly than methane concentrations (Brook et al.,

\footnotetext{
${ }^{3}$ Detailed temporal resolution of changes in temperature and $\mathrm{CH}_{4}$ concentrations has been complicated by the fact that air trapped in ice and snow continues to be influenced by atmospheric concentrations until sealed into impermeable bubbles. This produces a difference between gas age and ice age that can range from 30 years up to 7000 years, depending on the site's accumulation rate (Bender et al., 1997).
}

2000). The fact that the majority of $\mathrm{CH}_{4}$ increase lagged the warming thus seems to rule out the primarily causal role of $\mathrm{CH}_{4}$ in glacial-interglacial climate change.

\subsubsection{Pre-industrial to present concentrations}

Measurements from polar ice cores over the past 1000 years reveal several notable features in global $\mathrm{CH}_{4}$ concentrations. These include: (1) variations of $10-15$ ppbv about a pre-industrial level of $700 \mathrm{ppb}$; (2) a pole-to-pole gradient of $30-60 \mathrm{ppb}$ increasing to around $150 \mathrm{ppb}$ in this century, indicating consistently larger emissions in the Northern Hemisphere, but variable tropical emissions; (3) a continued correlation with temperature during the Little Ice Age around the middle of the millenium; and (4) a significant and monotonic increase beginning between 1750 and 1800 (Etheridge et al., 1998; Chappellaz et al., 1997; Blunier et al., 1993; Nakazawa et al., 1993; Khalil and Rasmussen, 1987; Craig and Chou, 1982). This increase is confirmed by glacial ice cores from the early 1800s (e.g., Dibb et al., 1993), and solar spectra from 1950 (e.g., Rinsland et al., 1985). As seen in Fig. 2, ice core records and observations from ground-based stations show that the global level of methane has more than doubled since preindustrial times, and continues to increase (Rasmussen and Khalil, 1981; Blake and Rowland, 1988; Steele et al., 1992; Dlugokencky et al., 1994a, 1995, 1998; scientific reviews can be found in IPCC, 1995, 1996).

Numerous modelling studies (e.g., Khalil and Rasmussen, 1985; Thompson, 1992; Crutzen and Bruhl, 1993; Khalil and Rasmussen, 1994b; Osborn and Wigley, 1994; Crutzen, 1995; Brasseur et al., 1998; Lelieveld et al., 1998; Wang et al., 1998) show a decline in the hydroxyl radical sink for $\mathrm{CH}_{4}$ from pre-industrial times to the present. Modelled $\mathrm{OH}$ decreases center around $10-30 \%$, depending on the model used, with the range also caused by large uncertainties in past emissions of other trace gases such as $\mathrm{CO}, \mathrm{NO}_{x}$ and NMHCs. This range, combined with analyses of past emissions (Khalil and Rasmussen, 1985, 1994a; Lelieveld et al., 1993; Subak, 1994; Stern and Kaufmann, 1996), shows that the majority of the observed increase in methane since pre-industrial times is due to the increase in emissions from anthropogenic sources, as shown in Fig. 3. 


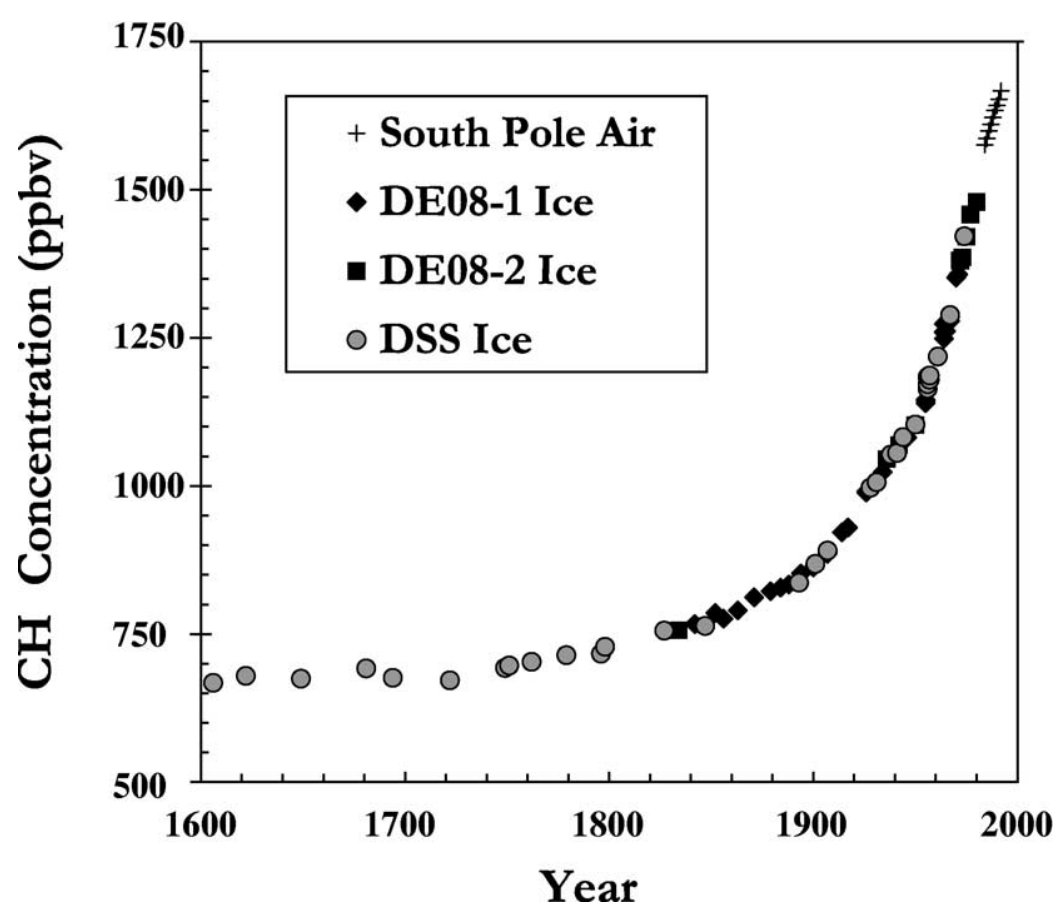

Fig. 2. Ice core and atmospheric records of the increase in atmospheric methane from pre-industrial times to the present (source: Etheridge et al., 1998).

Khalil and Rasmussen (1987, 1994a) find good agreement between increasing population, agricultural emissions, and the observed rise in emissions over the past 200 years, and it is also likely that increasing fossil fuel use has contributed significantly (Etheridge et al., 1992, 1998; Dlugokencky et al., 1994a). However, studies of human populations and activities over the past millenium suggest that discernable anthropo-

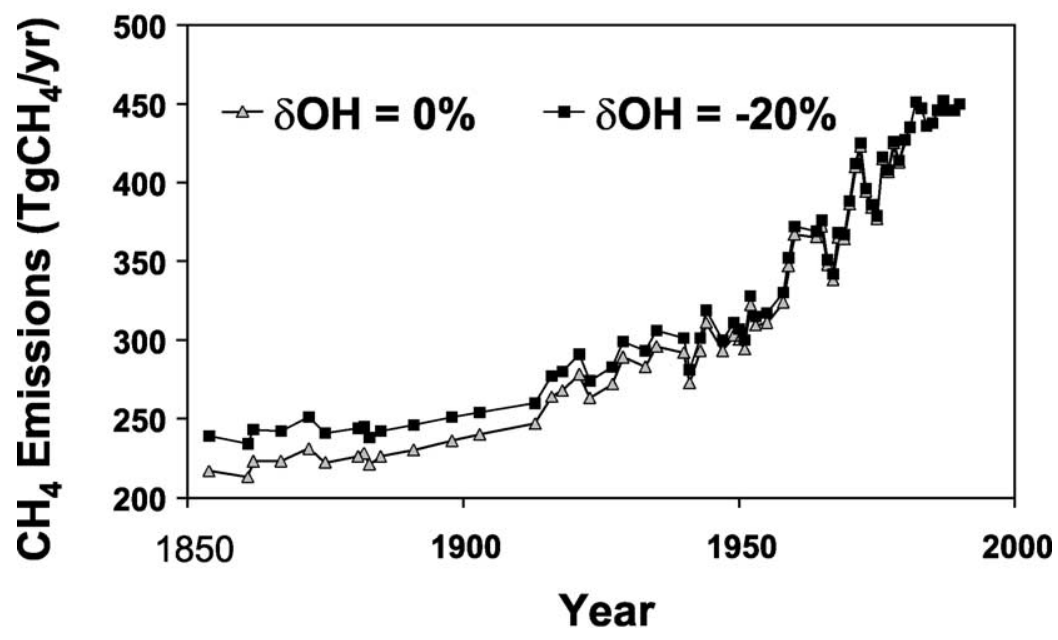

Fig. 3. Increase in methane emissions from pre-industrial times to the present. Based on a top-down analysis by Khalil and Rasmussen (1994a). 
genic influence on $\mathrm{CH}_{4}$ may extend back considerably further than the beginning of the pre-industrial age (Subak, 1994; Blunier et al., 1993).

\subsubsection{Decadal changes in methane growth rates}

The rate of increase for methane throughout the late 1970s averaged 20 ppbv/year (Blake and Rowland, 1988). However, during the 1980s and 1990s, the rate of methane increase slowed steadily, by an average of $-1 \mathrm{ppb} / \mathrm{year} / \mathrm{year}$ (Fig. 4). Continuous monitoring of methane trends in ambient air from 1979 to 1989 indicated a decreasing trend from 20 to just over $10 \mathrm{ppbv}$, with an average growth rate of 8.9 ppbv/year from 1984 to 1996 (Dlugokencky et al., 1994a, 1998; Khalil and Rasmussen, 1993, 1994b; Steele et al., 1992). When the data were examined for regional and seasonal effects, it was found that the slowing in the rate of increase is higher between 30 and $90^{\circ} \mathrm{N}$ (Dlugokencky et al., 1998; Steele et al., 1992), but that the amplitude of the seasonal cycle has exhibited no significant global trends over this time, with typical amplitudes around $30 \mathrm{ppb}$ in the high
Southern latitudes, $60 \mathrm{ppb}$ in the high Northern latitudes, and only a small change in the tropics (Khalil et al., 1993a; Dlugokencky et al., 1994a, 1997).

Following the 1992-1993 anomaly (discussed in the following section), the rate of methane increase continued to fall to a value of 3 ppbv/year in 1996, with a globally-averaged atmospheric concentration of $1730 \mathrm{ppbv}$ and an interhemispherical gradient of 140 ppbv (Dlugokencky et al., 1994a, 1998). If the current decrease in trend had continued, zero growth was expected to occur before 2006, as concentrations slowly stabilized around 1800 ppbv (Etheridge et al., 1998; Dlugokencky et al., 1998).

The long-term slowing in the rate of $\mathrm{CH}_{4}$ increase over the last few decades must be due to either an increase in methane removal, or declining methane emissions. Observed trends in the seasonal cycle of methane and global $\mathrm{OH}$ concentrations inferred from methylchloroform measurements do not support a significant change in $\mathrm{OH}$ over the past decades (Dlugokencky et al., 1997; Prinn et al., 1995). Similarly,

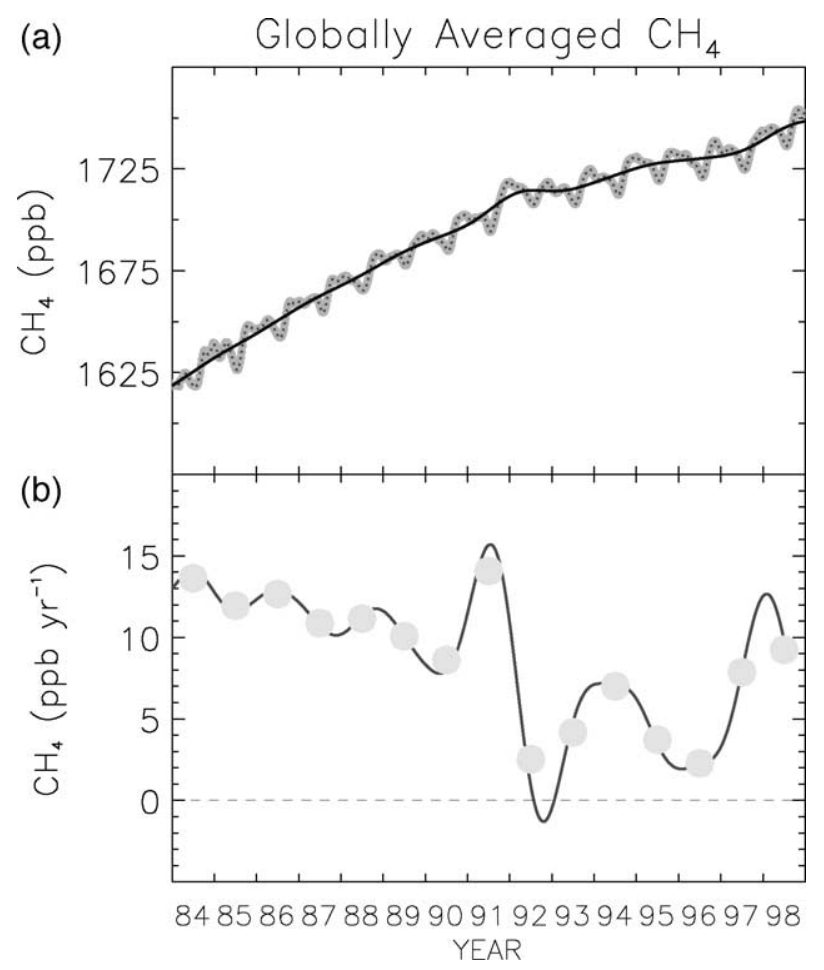

Fig. 4. (a) Observed increase in atmospheric methane concentrations and (b) growth rate (source: Dlugokencky, personal communication). 
modelling studies investigating the impact of observed stratospheric ozone depletion and temperature change over the past decade found that, although the resulting increase in $\mathrm{OH}$ is compatible with the observed decrease in trend, by themselves these two factors are insufficient to account for the entire decrease in growth rate (Bekki and Law, 1997; Fuglestvedt et al., 1994). Isotopic analysis shows the growth rate of $\delta^{13} \mathrm{C}$ over that time to be inconsistent with a substantial increase in the $\mathrm{CH}_{4}$ sink (Etheridge et al., 1998). It appears, then, that decreasing changes in emissions rather than increasing sink strengths must be responsible for the major part of the observed slowing.

In the absence of any mechanism to explain a longterm decrease in natural sources such as wetlands, the answer appears to lie with anthropogenic emissions. Khalil and Rasmussen (1994a,b) examine the changing relationship between population and agricultural sources, thought to be a major contributor to $\mathrm{CH}_{4}$ increases from pre-industrial to present times, to show that the growth in agricultural sources may be slowing. Steele et al. (1992) suggest that human sources, particularly those sources which can be reduced quickly, may be the cause of the observed rapid deceleration of the growth rate in the Northern relative to the Southern Hemisphere. Although the exact cause of this long-term decline in the global methane rate is still unresolved, Dlugokencky et al. (1998) suggested that what had been observed was in fact an approach to steady state, as $\mathrm{CH}_{4}$ net emissions and $\mathrm{OH}$ levels were nearly constant over the past decade.

Optimistic projections of stabilizing atmospheric $\mathrm{CH}_{4}$ levels in the near future have been set back by the latest measurements of $\mathrm{CH}_{4}$ growth rates that show a jump back up to growth rates of $8-12 \mathrm{ppbv} /$ year in 1997 and 1998 (Fig. 4, Dlugokencky, personal communication). Although net methane sources may have been relatively constant over the past two decades, it is likely that changes in the distribution of methane sources were occurring during that time, with increases in some sources equalling decreases in others (Dlugokencky et al., 1998). What may be occurring now is an increase in emissions from $\mathrm{CH}_{4}$ source(s) that is larger than can be balanced by concurrent decrease in other source(s). It has been speculated, supported by ${ }^{13} \mathrm{C}$ isotope observations, that the recently observed increase could in fact be the first sign of a biospheric feedback to climate change, as wetland emissions increase in response to the climate warming (Manning, personal communication). Observations of anonymously high temperatures and the lack of an obvious reason for a decrease in the $\mathrm{OH}$ sink of methane over this time provide indirect evidence in support of this hypothesis. However, it is equally true that the observed increase in growth rate could also be merely another temporary interannual variation as has been observed before (Dlugokencky, personal communication). Whatever the true cause of this increase, though, it serves at this time to emphasize our limited understanding of the factors that influence methane sources and sinks, and the large uncertainty this introduces in projections of future concentrations.

\subsubsection{1-1994 drop in growth rates}

In 1991, the growth rate of methane increased sharply over a period of 6 months to 1 year following the eruption of Mt. Pinatubo in June. The growth rate then dropped abruptly to very low values and even zero in some locations from 1992 to 1993. Average growth rate in 1992 was only $1.8 \mathrm{ppb} /$ year in the Northern Hemisphere, and $7.7 \mathrm{ppb} /$ year in the Southern Hemisphere (Dlugokencky et al., 1994a,b; 1998), producing a decrease in atmospheric concentrations that has recently been observed in lower stratospheric $\mathrm{CH}_{4}$ concentrations, which lag 4 years behind the troposphere (Randel et al., 1999). In 1994, global methane growth rates recovered back up to about 8 ppbv/year, before continuing the previously observed long-term decrease (Dlugokencky et al., 1998). A number of theories suggesting reductions in emissions from anthropogenic or natural sources or a slowing in the rate of $\mathrm{CH}_{4}$ removal have been proposed to explain this short-term anomaly.

Aerosols released by the Pinatubo eruption blocked UV radiation to the troposphere, which may have led to a drop in $\mathrm{OH}$ levels and a consequent sharp increase in the methane growth rate. Dlugokencky et al. (1996) show the initial short-lived increased growth rate to be consistent with this theory; however, the causes for the subsequent decrease in the growth rate have not been resolved.

Increases in tropospheric $\mathrm{OH}$ have also been proposed as causes for the short-term drop, through mechanisms such as El Niño-induced increases in tropospheric water vapor, an important source of 
OH (Khalil and Rasmussen, 1993), or aerosol-induced stratospheric ozone depletion, which would cause an increase in tropospheric UV radiation and a subsequent rise in $\mathrm{OH}$ formation (Bekki et al., 1994). Enhanced mixing of stratospheric air, with its lower $\mathrm{CH}_{4}$ levels, has also been proposed to result from increased stratospheric temperatures following the Pinatubo eruption (Schauffler and Daniel, 1994). Reductions in emissions from tropical biomass burning, Northern Hemisphere fossil fuel sources, or wetlands have also been put forward as possible contributors to the brief but abrupt slowing (Lowe et al., 1994, 1997; Dlugokencky et al., 1994b; Law and Nisbet, 1996; Hogan and Harriss, 1994).

The ability of these theories to match the observed drop have been constrained by a number of observational and modelling studies comparing source strengths, mixing ratios, and isotopic abundances. Comparison of regional mixing ratios with $\delta^{13} \mathrm{C}$ isotopic measurements (as discussed in the following section) suggest that changes in atmospheric chemistry or wetland emissions played a minimal role. Instead, observations support a decrease in $\delta^{13} \mathrm{C}$-enriched sources such as biomass burning in the Southern Hemisphere or fossil fuel use in the Northern Hemisphere (Lowe et al., 1994, 1997; Gupta et al., 1996). However, using isotopic measurements from six sites, Quay et al. (1999) were unable to distinguish between the possible impacts of changes in biogenic sources, fossil sources, or $\mathrm{OH}$ concentration over this time. In addition, it has been shown that a change in the atmospheric $\mathrm{CH}_{4}$ sink may not be detectable in $\delta^{13} \mathrm{C}$ for some time (Tans, 1997; Lassey et al., 1999).
Both modelling studies and recent isotopic analyses therefore conclude that several of these mechanisms may have combined to produce the observed drop in growth rates. Estimated changes in individual sources or sinks, with moderate assumptions of their sensitivity to Pinatubo-induced chemistry and temperature changes and to human activities, are individually insufficient to account for the entire decrease (Bekki and Law, 1997; Lelieveld et al., 1998).

\subsection{Sources and sinks}

\subsubsection{Sources}

Methane differs from carbon dioxide in that it is released into the atmosphere by a wide variety of sources, both natural and anthropogenic. Anthropogenic emissions arise from biogenic sources related to agriculture and waste disposal, including enteric fermentation, animal and human wastes, rice paddies, biomass burning, and landfills (Fig. 5). Methane is also emitted by the extraction of fossil fuels such as natural gas, coal, and petroleum. Natural methane emissions arise from wetlands, termites, other wild ruminants, oceans, and hydrates (Fig. 6). Based on recent estimates, current human-related biogenic and fossil fuel-related sources for methane are approximately 275 and $100 \mathrm{TgCH}_{4}$ /year, while total natural sources are around $160 \mathrm{TgCH}_{4} /$ year (IPCC, 1996).

Due to the variety of methane sources, emissions are affected by numerous factors, including energy use, human population distributions, agricultural practices, and climate. As discussed in the previous section, there is strong evidence that methane emis-

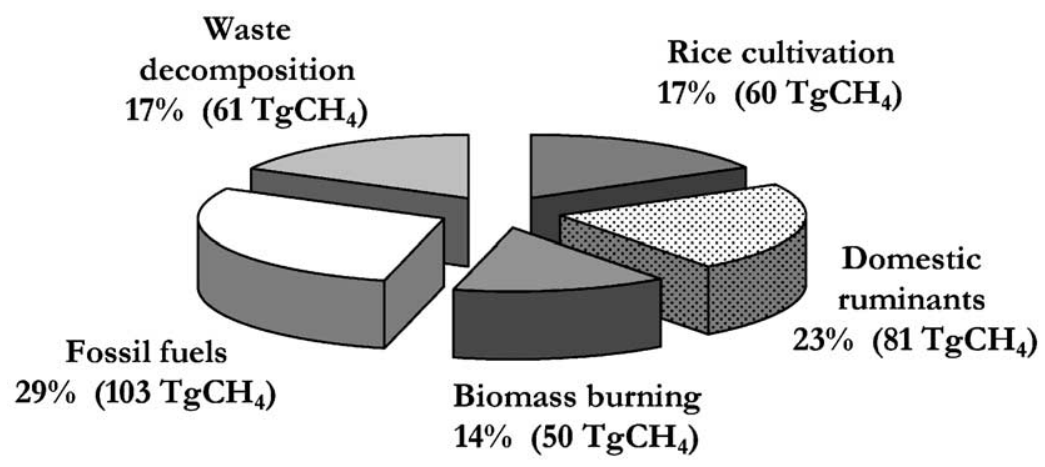

Fig. 5. Contribution of individual sources to total anthropogenic methane emissions (based on Khalil, 2000). 


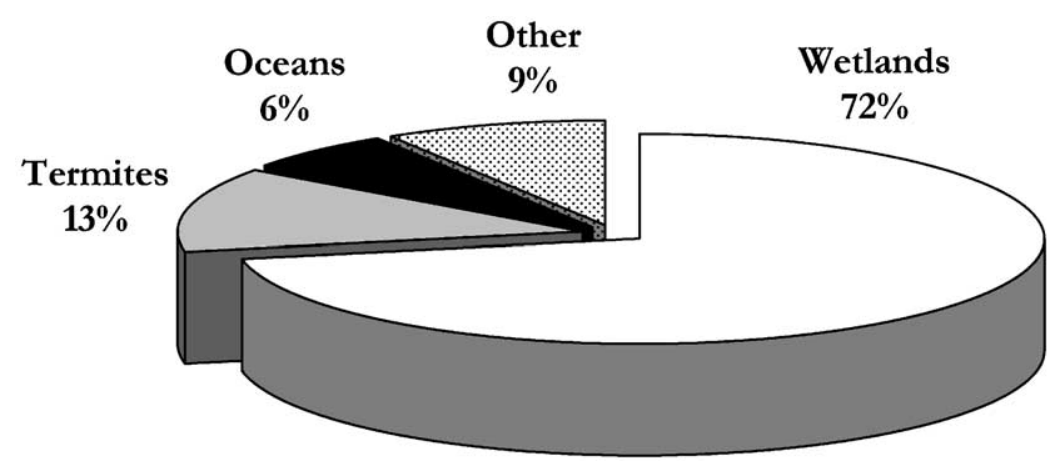

Fig. 6. Contribution of individual sources to total natural methane emissions (based on Khalil, 2000).

sions are changing over time. Here, we briefly describe the main factors influencing the magnitude of emissions from each major source, and how those factors could change under greenhouse gas controls or climate change.

2.2.1.1. Biogenic sources. Methane emissions from biogenic sources result from anaerobic decomposition and reduction of organic material by bacteria - in flooded soils, in landfills or other waste disposal sites, and in the digestive tracts of domestic ruminants such as cattle or sheep, wild ruminants such as buffalo or termites, and even humans. It has been determined that methane production is temperature-dependent, with maximum growth temperature ranging from $37^{\circ} \mathrm{C}$ to $45^{\circ} \mathrm{C}$ (Boone, 2000). This temperature dependence is an important factor with implications of future changes for emissions from flooded soils, such as wetlands or rice paddies. It represents an important positive feedback on climate change - as the atmosphere warms, emissions from these sources will increase, raising the concentration of $\mathrm{CH}_{4}$ in the atmosphere and enhancing the warming.

Emissions from natural wetlands are influenced by a wide range of environmental parameters. These include soil characteristics such as the availability of organic carbon and nutrients (Cao et al., 1996b; Miller et al., 1999; Smith et al., 2000; Yavitt et al., 2000), vegetation type and cover (King et al., 1998; Bellisario et al., 1999; Joabsson et al., 1999; Van der Nat and Middelburg, 2000), and, most importantly, water table depth and soil temperature. A number of studies have demonstrated the high sensitivity of wetland emissions to seasonal and interannual variations in water table and temperature (e.g., Moosavi and Crill, 1997, 1998; Oberbauer et al., 1998; Van den Pol-Van Dasselaar et al., 1999; Wickland et al., 1999; Nakano et al., 2000; Otter and Scholes, 2000; Worthy et al., 2000; see review in Matthews, 2000). This sensitivity will play a significant role in determining future wetland emissions, as local temperature and precipitation patterns are altered under global climate change. Based on projected temperature increases alone, $\mathrm{CH}_{4}$ emissions are expected to increase, particularly at high latitudes (Cao et al., 1996b; Matthews, 2000; Worthy et al., 2000). However, the influence of soil moisture and water table level complicates predictions of future wetland emissions. The impact of global climate change on the hydrological cycle at regional levels is highly uncertain; thus, future changes in soil water may result in either increases or decreases in current wetland areas and their emissions (e.g., Wahlen and Reeburgh, 1992; Roulet et al., 1993; Moosavi et al., 1996; Moosavi and Crill, 1997; Van den Pol-Van Dasselaar et al., 1999; Hilbert et al., 2000).

In rice fields, emissions are dependent on the conditions and agricultural practices employed during cultivation, such as climate, soil characteristics, and cultivation practices including water management, fertilizers, other additives, and different varieties of rice plants (e.g., Minami and Neue, 1994; Cao et al., 1995, 1996a; Huang et al., 1997, 1998; Neue et al., 1997; Sass and Fisher, 1997; Khalil et al., 1998; Neue and Roger, 2000). Emissions are also determined by the number of crops per year and the total area under cultivation, which is a function of the demand for rice, and the amount of rice produced per hectare, or 'yield'. Practices such as occasional draining of the 
fields, the addition of oxidents or other mineral fertilizers, and selection of low $\mathrm{CH}_{4}$ cultivars have been found to reduce emissions by approximately $40-55 \%, 20-70 \%$ and up to $60 \%$, respectively (EPA, 1993a,b; Neue et al., 1997; Sigren et al., 1997; Yagi et al., 1997; Butterbachbahl et al., 1997; Cole et al., 1997; Minami, 1997; Sass and Fisher, 1997; Mitra et al., 1999). Alternatively, the addition of organic fertilizers has the potential to increase emissions by over $50 \%$ relative to non-organic fertilizers (e.g., Buendia et al., 1997; Denier van der Gon and Neue, 1995; Yagi et al., 1997).

Direct emissions from ruminants, including cattle, sheep, buffalo, goats, and other domestic animals, are affected by diet (Johnson et al., 2000; EPA, 1993a,b; Cole et al., 1997; Harper et al., 1999). Methane emissions are a byproduct of incomplete digestion. In general, higher quality diets will allow animals to digest their food more completely, improving protein uptake while reducing $\mathrm{CH}_{4}$ emissions. This is particularly true of ruminant diets in developing countries, where improving the relatively poor quality of cattle feed could lead to emission reductions per $\mathrm{kg}$ of milk produced of up to $75 \%$ (Ward et al., 1993; Crutzen et al., 1986). The addition of production-enhancing supplements to cattle diet has also been suggested as a means to improve digestion and reduce emissions by up to $40 \%$ (EPA, 1993a,b; Cole et al., 1997 and references therein). Animal manure is an additional source of methane. If animal waste is allowed to remain in the field, the manure dries quickly and methane emissions are minimal. However, if the waste is pooled and stored, methane emissions can rise by a factor of 10 (Bogner et al., 1995).

Methane is also emitted by the decay of biogenic waste in the anaerobic environments provided by landfills and wastewater pools. Emissions from landfills are affected by numerous environmental and technical variables, including temperature, soil moisture, and $\mathrm{CH}_{4}$ concentration within the landfill; the amount, organic composition, and age of the waste; and the thickness of the overlying layer. (Bogner and Spokas, 1993; Peer et al., 1993; Czepiel et al., 1996). Emissions from landfills, wastewater, and manure collection lagoons can be reduced by trapping the methane before it is released to the atmosphere, and either flaring it or using it as an energy source. Depending on the capture efficiency, this method can reduce emissions by over $90 \%$ (e.g., Bogner et al., 1995; Borjesson and Svensson, 1997).

Biomass burning releases numerous pollutants into the atmosphere. When combustion is complete, most of the emissions consist of carbon dioxide. However, if the fires smolder and combustion is incomplete, large amounts of $\mathrm{CH}_{4}$ and other higher-order hydrocarbons can be produced. Methane emissions from biomass burning depend on the stage of combustion reached, as well as on the carbon content of the biomass, and the amount of biomass burned (Levine et al., 2000).

2.2.1.2. Non-biogenic sources. The main source of fossil-fuel related methane emissions are the leaks that occur during natural gas processing, transmission, and distribution, since natural gas is over $90 \%$ methane (e.g., Beck et al., 1993; EPA, 1993a). The magnitude of this source depends directly on the loss rate, which has been estimated to average between $1 \%$ to $2 \%$ of natural gas production for developed countries (GRI, 1997; Beck et al., 1993; EPA, 1993b; Barns and Edmonds, 1990). Uncertainty remains substantial, however, as these values are based mainly on the analysis of gas systems in developed countries where transportation is likely to be more tightly controlled than in less developed nations (Kirchgessner, 2000). Regional leakage percentages have been estimated to range from $1 \%$ to $15 \%$ of total natural gas production, depending on the quality of the pipelines, the extraction process, leakage control, the method used to estimate gas losses, and other factors (e.g., Mitchell, 1993; Matthews, 1994; Bazhin, 1994; Beck et al., 1993).

Methane is also emitted from coal mines, when gas that has been trapped between layers of coal during its formation is released as the coal is mined. Global and even regional estimates of $\mathrm{CH}_{4}$ emissions from coal and mines depend on many assumptions regarding the type of coal, the depth of the mine, mining practices, the methane content of the coal seam, and whether methane is flared or released (Beck et al., 1993; Kirchgessner, 2000, and references therein).

Lacking viable sources of alternative energy, methane emissions from coal mining and natural gas use may be more easily reduced by altering mining practices and improving gas leakage controls than 
by avoiding coal or gas use. If methane emitted from these sources can be trapped, it can be used as an energy source, providing additional benefits.

\subsection{2. $\mathrm{CH}_{4}$ sinks}

In contrast to the numerous sources of methane, there are only one major and two minor sinks for tropospheric methane. Reaction with the hydroxyl radical $(\mathrm{OH})$ is responsible for the removal of approximately $500 \mathrm{TgCH}_{4} /$ year (almost $90 \%$ of the total sink), making the concentration of $\mathrm{OH}$ the most important determinant of the rate at which methane is removed from the atmosphere. The remainder of the $\mathrm{CH}_{4}$ is removed through dry soil oxidation, 30 $\mathrm{TgCH}_{4} /$ year $(\sim 5 \%)$, and transport to the stratosphere, estimated at $40 \mathrm{TgCH}_{4} /$ year $(\sim 7 \%)$ in IPCC (1996), but recently found to be only $27 \mathrm{TgCH}_{4} /$ year based on data from the Upper Atmosphere Research Satellite (Gettelman et al., 1997).

$\mathrm{OH}$ is formed from the photodissociation of tropospheric ozone and water vapor. It is the primary oxidant for most tropospheric pollutants, including carbon monoxide, $\mathrm{NO}_{x}$ species, and organic compounds (e.g, Crutzen, 1995). As the most abundant organic species in the atmosphere, methane plays an influential role in determining the tropospheric oxidizing capacity, initiating an important series of chemical reactions (see discussion in Wuebbles et al., 2000). The oxidation of methane by $\mathrm{OH}$ is so effective that almost $90 \%$ of methane destruction currently occurs in the troposphere due to these reactions (e.g., IPCC, 1996). The amount of methane removed is constrained by $\mathrm{OH}$ levels and the rate constant of the reaction.

With sharp spatial and temporal gradients, and average concentrations of one part per 50 trillion, the actual concentration of $\mathrm{OH}$ is difficult to determine, much less its rate of formation or destruction, which depends non-linearly on the other factors mentioned above (e.g., Thompson, 1992; Crutzen, 1995). A few measurements of $\mathrm{OH}$ have been made at certain locations using long-path absorption spectroscopy (e.g., Hofzumahaus et al., 1991; Poppe et al., 1995), and confidence in the accuracy of direct measurements is growing (Brune, 1992). However, most estimates of $\mathrm{OH}$ concentration have been obtained through measuring the concentration of a tracer molecule such as methylchloroform $\left(\mathrm{CH}_{3} \mathrm{CCl}_{3}\right)$ that can be used to infer the $\mathrm{OH}$ concentration with a chemical transport model. Using $\mathrm{CH}_{3} \mathrm{CCl}_{3}$ data from 1978 to 1994 obtained at five ALE/GAGE stations around the globe, modelling studies deduced the average globally integrated concentration of $\mathrm{OH}$ to be $9.7 \times 10^{5}$ (Prinn et al., 1995) and $1.07 \times 10^{6} \mathrm{~mol}$ ecules $/ \mathrm{cm}^{3}$ (Krol et al., 1998). Over the same time period, the studies by Prinn and Krol obtained a change in $\mathrm{OH}$ concentration of $0.0 \pm 0.2 \%$ /year and $0.46 \pm 0.5 \%$ /year, respectively. Based on changes in emissions of $\mathrm{CO}, \mathrm{NO}_{x}$, and NMHCs evaluated with a three-dimensional model of the troposphere, Karlsdottir and Isaksen (2000) estimated that tropospheric $\mathrm{OH}$ concentrations have increased by about $7 \%$ from 1980 to 1996 , or $0.43 \%$ /year. According to Karlsdottir and Isaksen (2000), the corresponding decrease in atmospheric lifetime of $\mathrm{CH}_{4}$ when combined with the observed record would imply overall $\mathrm{CH}_{4}$ emissions increasing at a rate of $0.67 \% /$ year over this period.

$\mathrm{OH}$ concentrations are affected not only by direct emissions of methane but by its oxidation products, especially carbon monoxide. Methane has an atmospheric lifetime of $8.9 \pm 0.6$ years based on $\mathrm{CH}_{3} \mathrm{CCl}_{3}$ analyses and good knowledge of the loss rate with $\mathrm{OH}$ (Prinn et al., 1995). This is lower than the previous estimate of 10 years (WMO, 1991, 1995). Although most trace gases have a turnover time which describes the length of time they are present in the atmosphere, methane is removed by $\mathrm{OH}$ on an 'adjustment' time scale that exceeds the atmospheric lifetime by approximately 3 years (e.g., Prather, 1994; IPCC, 1996). The feedback factor that describes this relationship, which is the ratio of the adjustment time of methane to its atmospheric lifetime, varies from 1.2 to 1.7 , depending on the model used in the evaluation. Comparisons of $2 \mathrm{D}$ and $3 \mathrm{D}$ models suggest that the factor does not depend strongly on the background atmospheric $\mathrm{OH}$ levels (IPCC, 1996).

This discrepancy between adjustment time and chemical lifetime is due to the fact that the hydroxyl radical is removed not only by interactions with $\mathrm{CH}_{4}$, but also with its product, $\mathrm{CO} . \mathrm{CH}_{4}, \mathrm{CO}$, and $\mathrm{OH}$ are involved in a chemical feedback cycle whereby even a small rise in the background level of methane - due to growing emissions - will reduce $\mathrm{OH}$ and produce $\mathrm{CO}$. The carbon monoxide produced by $\mathrm{CH}_{4}$ oxidation will in turn be oxidized by $\mathrm{OH}$, 
causing a further drop in $\mathrm{OH}$ levels. This extra decrease in $\mathrm{OH}$ results in an increase in the lifetime of methane, thereby enhancing the original perturbation. The result is a positive feedback, whereby increasing methane emissions can lead to an overall decrease in the oxidizing capacity of the troposphere, a slowing in the removal of methane, and a consequent build-up of methane concentrations. Thus, an incremental perturbation in $\mathrm{CH}_{4}$ will return to an equilibrium concentration at a slower rate than expected from the atmospheric lifetime, even though there may be no apparent measurable change in $\mathrm{OH}$.

\subsubsection{Isotopic composition}

The isotopic composition of atmospheric methane is determined by specific chemical and physical processes that, when understood, can yield valuable information concerning the strength of methane sources and sinks, and their contribution to changes in atmospheric methane. The most commonly measured isotope of atmospheric methane is ${ }^{13} \mathrm{C}$, which is generally expressed as $\delta^{13} \mathrm{C}$, the ratio of ${ }^{13} \mathrm{C}$ to ${ }^{12} \mathrm{C}$ relative to a reference standard. The $\delta^{13} \mathrm{C}$ ratios can be used to differentiate between methane from bacterial sources, which are ${ }^{13} \mathrm{C}$-depleted relative to atmospheric methane, and the ${ }^{13} \mathrm{C}$-enriched methane emitted from non-bacterial sources such as natural gas and biomass burning, which is generally 20$30 \%$ greater (Tyler, 1986; Tyler et al., 1987; Cicerone and Oremland, 1988; Quay et al., 1988; Stevens and Engelkemeir, 1988; Conny and Currie, 1996, and references therein).

The global average atmospheric $\delta^{13} \mathrm{C}$ ranges from $-47.3 \%$ o to $-46.2 \%$ (Stevens and Rust, 1982; Stevens, 1993; Quay et al., 1991, 1999; Tyler et al., 1999). Atmospheric $\delta^{13} \mathrm{C}$ is enriched relative to the global composite of methane sources, which is approximately $-53 \%$, based on estimates of source strengths (Quay et al., 1991; Lassey et al., 1999). This $\delta^{13} \mathrm{C}$ enrichment is due to the kinetic isotope effect (KIE) during the reaction of $\mathrm{CH}_{4}$ with $\mathrm{OH}$, which preferentially removes ${ }^{12} \mathrm{C}$ with a fractionation effect at least 1.0054 (Cantrell et al., 1990). Soil oxidation also preferentially removes

${ }^{12} \mathrm{C}$, as do reactions with $\mathrm{Cl}$ in the stratosphere. Fractionation effects for these sinks are thought to be larger than those for OH (King et al., 1989, Tyler et al., 1994, 2000; Brenninkmeijer et al., 1995; Saueressig et al., 1995; Crowley et al., 1999; Snover and Quay, 2000).

The radioactive isotope ${ }^{14} \mathrm{C}$ also provides valuable information on $\mathrm{CH}_{4}$ sources. ${ }^{14} \mathrm{C}$ from bomb tests in the 1960 s and current ${ }^{14} \mathrm{C}$ emissions from pressurized light-water reactors enables differentiation between modern (enriched) sources of methane and fossil (depleted) sources. Based on ${ }^{14} \mathrm{C}$ measurements, fossil sources are estimated to range from 16 to $25 \%$ of total $\mathrm{CH}_{4}$ emissions (Wahlen et al., 1989; Manning et al., 1990; Quay et al., 1991, 1999). Together with the $\delta^{13} \mathrm{C}$ ratio, this information can be used to deduce the contribution of biomass burning - a modern but non-bacterial source - to the current budget. Estimates center around 10-11\% (Wahlen et al., 1989; Fung et al., 1991; Quay et al., 1991; Stevens, 1993).

Systematic $\delta^{13} \mathrm{C}$ measurements have shown a seasonal cycle that increases with latitude, $180^{\circ}$ out of phase with the seasonal change in $\mathrm{CH}_{4}$ concentrations (Quay et al., 1991, 1999; Lassey et al., 1993; Lowe et al., 1994, 1997; Francey et al., 1999). In the tropical latitudes the cycle may be due to seasonal variations in $\mathrm{OH}$ concentrations, whereas at higher latitudes it is thought to be source-driven (Quay et al., 1999). In the Northern Hemisphere, seasonal isotopic variability may be caused by a strong pulse of $\delta^{13} \mathrm{C}$-depleted $\mathrm{CH}_{4}$ emissions together with possible transport from lower latitudes, while seasonal variations in biomass burning are thought to be responsible for the Southern Hemisphere cycle (Quay et al., 1991, 1999; Lassey et al., 1993; Lowe et al., 1994; Tyler, 1999). The role of biomass burning is emphasized in a recent study by Lowe et al. (1999), who find seasonal variations to be divided into three distinct latitude bands, two of whose cycles - tropical and Southern Hemisphere extra-tropical - correlate strongly with seasonal emissions from biomass burning and their transport to higher latitudes.

$\delta^{13} \mathrm{C}$ records also indicate long-term trends. Isotopic measurements from ice cores give a pre-industrial atmospheric $\delta^{13} \mathrm{C}$ of $-49.7 \%$ (Craig et al., 1988). Together with an estimate of the sink fractionation factor, this implies an increase in the global composite $\delta^{13} \mathrm{C}$ of approximately $2 \%$ since preindustrial times (Quay et al., 1988; Etheridge et al., 1998). A lower $\delta^{13} \mathrm{C}$ suggests that historical emissions were controlled primarily by natural sources. Comparison of present-day atmospheric isotope ratios with 
ice core data gives flux estimates for current bacterial emissions around $70 \%$ of the total budget (Quay et al., 1991).

Systematic $\delta^{13} \mathrm{C}$ measurements taken for over two decades at various sites distributed around the globe indicate that the atmosphere is becoming progres- sively more enriched in ${ }^{13} \mathrm{C}$, as shown in Fig. 7 (Stevens, 1993; Etheridge et al., 1998; Francey et al., 1999; Quay et al., 1999). Studies suggest that the global increase may be source-driven, caused by increases in $\delta^{13} \mathrm{C}$-enriched emissions from biomass burning in the Southern Hemisphere, and a possible
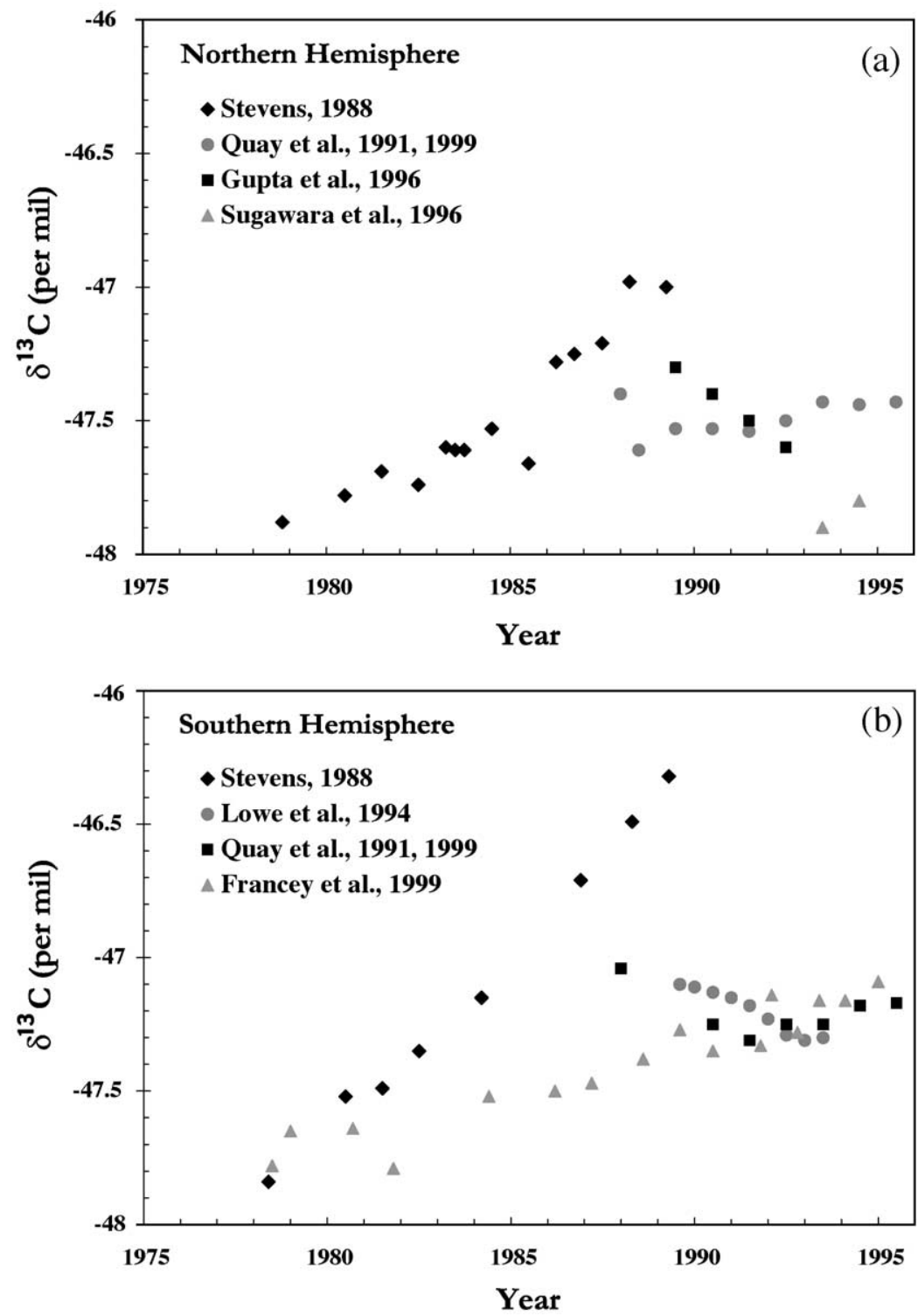

Fig. 7. Measurements of the carbon-13 isotopic composition of atmospheric methane from 1978 to 1995 . Hemispherically and annually averaged data was collected at a number of sites in (a) the Northern Hemisphere, and (b) the Southern Hemisphere (Source: Stevens and Wahlen, 2000, and references therein). 
decrease in ${ }^{13} \mathrm{C}$-depleted Northern Hemisphere sources such as wetlands and rice paddies (Stevens, 1993). Recent Southern Hemisphere measurements covering the period from 1978 to 1996 indicate any such redistribution in sources to have been relatively small (Francey et al., 1999). Measurements over the same time period also show steady increases in ${ }^{14} \mathrm{C}$ due to emissions from reactors; however, its growth rate began to slow in 1993 due to a shift away from nuclear power (Quay et al., 1999).

\subsubsection{Budget modelling}

Uncertainties in sources and sinks of methane are constrained by direct estimates of the individual magnitudes of each source and sink. Source-specific estimates are generally made by multiplying an average emission rate, determined experimentally, by an extrapolant that applies that emission rate over the globe. ${ }^{4}$ Although conceptually simple, this bottomup method contains numerous uncertainties. First, point measurements taken at a limited number of locations and times must be assumed to be representative of global emissions. In the past, this has led to over-estimates of emissions from a number of sources, including rice cultivation (Sass et al., 1999), livestock (Johnson et al., 2000) and possibly wetland emissions (Worthy et al., 2000). It is also primarily responsible for the large ranges in estimates of emissions from other sources such as coal mining (Kirchgessner, 2000), biomass burning (Levine et al., 2000) and waste management (Thorneloe et al., 2000) seen in Table 1. However, as data coverage improves, attention is being re-focused on a second issue, that of resolving temporal and spatial variations in those emissions. Such variations are particularly important for biogenic sources such as wetlands and rice fields whose emissions can vary by several orders of magnitude depending on the location, time of day, season, or year (Matthews, 2000; Shearer and Khalil, 2000). Although these uncertainties continue to produce a range of values in the emission estimates for individual sources (Table 1), the range of estimates for most sources has decreased significantly not only due to the increase in the amount of experimental field data, but

\footnotetext{
${ }^{4}$ See Khalil and Shearer (2000) for a full discussion of the methods and constraints of bottom-up emissions estimates.
}

also due to the application of atmospheric $\mathrm{CH}_{4}$ data and other types of inventory estimates to the methane budget, as described next.

The methane budget is constrained by the spatial and temporal changes in atmospheric $\mathrm{CH}_{4}$ mixing ratios and isotopes discussed previously in Section 2.2.3. Isotopic composition of atmospheric methane is a particularly valuable source of information, as it reflects the relative strength of bacterial vs. nonbacterial and modern vs. fossil sources of $\mathrm{CH}_{4}$, as well as differentiating between various formation pathways (Cicerone and Oremland, 1988; Conny and Currie, 1996; Whiticar, 2000).

Mass-balance approaches use spatial and regional variations in isotopic composition as well as hemispheric and global averages as input to box models. Atmospheric observations are then compared with the flux-weighted composition of total emissions plus the fractionation effects of sinks, taking into account the effects of atmospheric transport. In this way, the magnitudes of individual sources as well as entire budgets have been estimated (e.g., Khalil and Rasmussen, 1983; Stevens and Engelkemeir, 1988; Cicerone and Oremland, 1988; Tyler, 1989; Lassey et al., 1993, 1999; Lowe et al., 1994, 1997; Quay et al., 1999).

Two- and three-dimensional chemical transport models are also used to perform calculations that match modelled emissions, concentrations, and carbon isotopes with observed abundances. In this way, uncertainties in sources and sinks can be reduced, and the relationships between methane emissions, atmospheric chemistry, and the climate system better quantified. A number of studies (Fung et al., 1991; Hein et al., 1997; Gupta et al., 1996) have used this approach, while others have developed new inversion methods (Brown, 1995; Kandlikar and McRae, 1995; Kandlikar, 1997; Houweling et al., 1999). These analyses, combined with multi-box and source-specific studies, produce comprehensive budgets of $\mathrm{CH}_{4}$ sources and sinks such as the composite estimate shown in Table 1 (Khalil, 2000).

\subsection{Projections of future concentrations}

Atmospheric methane concentrations have doubled since pre-industrial times. Increases in methane emissions from human sources such as rice cultivation, domestic ruminants, and increased fossil fuel use are 
Table 1

(a) Estimated natural and anthropogenic sources of methane $\left(\mathrm{TgCH}_{4} /\right.$ year $)$

\begin{tabular}{|c|c|c|c|}
\hline Source & $\begin{array}{l}\text { Emissions } \\
\left(\mathrm{TgCH}_{4} / \text { year }\right)\end{array}$ & $\begin{array}{l}\text { Range of } \\
\text { estimate }\end{array}$ & References \\
\hline Wetlands & 100 & $92-232$ & $\begin{array}{l}\text { Fung et al., 1991; Bartlett and Harriss, 1993; } \\
\text { Cao et al., 1996b; Hein et al., 1997; } \\
\text { Matthews, } 2000\end{array}$ \\
\hline Termites & 20 & $2-22$ & Sanderson, 1996; Sugimoto et al., 1998 \\
\hline Oceans & 4 & $0.2-2.0$ & $\begin{array}{l}\text { Bates et al., 1996; } \\
\text { Holmes et al., } 2000\end{array}$ \\
\hline Marine sediments & 5 & $0.4-12.2$ & Judd, 2000 \\
\hline Geological sources & 14 & $12-36$ & Judd, 2000, after Lacroix, 1993 \\
\hline Wild fires & 2 & & Levine et al., 2000 \\
\hline Total Natural & 145 & & \\
\hline Ruminants & 81 & $65-100$ & $\begin{array}{l}\text { Crutzen et al., 1986; Johnson et al., 2000; } \\
\text { IPCC, } 1995\end{array}$ \\
\hline Rice cultivation & 60 & $25-90$ & $\begin{array}{l}\text { Cao et al., 1996a; Neue and Sass, } 1998 \\
\text { and Yagi and Minami, } 1998 \text { as cited in } \\
\text { Sass et al., 1999; Shearer and Khalil, } 2000\end{array}$ \\
\hline Total Agricultural & 141 & & \\
\hline Natural gas & 30 & $25-50$ & $\begin{array}{l}\text { Cicerone and Oremland, 1988; } \\
\text { Fung et al., 1991; Kirchgessner, } 2000\end{array}$ \\
\hline Coal mining & 46 & $15-64$ & $\begin{array}{l}\text { Cicerone and Oremland, 1988; } \\
\text { Boyer et al., } 1990 \text { as cited in } \\
\text { Kirchgessner, 2000; Fung et al., 1991; } \\
\text { Kirchgessner et al., } 1993\end{array}$ \\
\hline Other fossil fuels & 30 & $6-60$ & Khalil et al., 1993b; Piccot et al., 1996 \\
\hline Biomass burning & 50 & $27-80$ & $\begin{array}{l}\text { Levine et al., 2000; based on estimates } \\
\text { by Seiler and Crutzen, 1980; Crutzen } \\
\text { and Andreae, 1990; and Hao and Ward, 1993; }\end{array}$ \\
\hline Waste disposal & 61 & $40-100$ & Johnson et al., 2000; Thorneloe et al., 2000 \\
\hline $\begin{array}{l}\text { Total Non-Agricultural } \\
\text { Anthropogenic }\end{array}$ & 217 & & \\
\hline TOTAL & 503 & $410-660$ & \\
\hline
\end{tabular}

(b) Estimated sinks of methane in $\mathrm{TgCH}_{4} /$ year (based on IPCC, 1995)

\begin{tabular}{lll}
\hline Sink & $\begin{array}{l}\text { Uptake } \\
\left(\mathrm{TgCH}_{4} / \text { year }\right)\end{array}$ & $\begin{array}{l}\text { Range of } \\
\text { estimate }\end{array}$ \\
\hline Tropospheric $\mathrm{OH}$ & 445 & $360-530$ \\
Removal to stratosphere & 40 & $32-48$ \\
Soil uptake & 30 & $15-45$ \\
TOTAL & 515 & $430-600$ \\
\hline
\end{tabular}

'Best guess' estimates are those given by the methane budget in Khalil (2000). Range of estimates is based on the most recent studies as cited here.

thought to be the primary contributors to the rapid rise that has been observed through records preserved in ice cores, solar spectra, and direct atmospheric measurements.

It is likely that future methane concentrations, however, will be strongly affected by changes in both sources and sinks of atmospheric methane. Projections of future methane concentrations therefore require modeling changes in both emission and removal rates of atmospheric methane, as well as considering feedbacks from climate change and emissions of other trace gases that affect both sources and sinks of $\mathrm{CH}_{4}$. 


\subsubsection{Projections of $\mathrm{CH}_{4}$ sources}

In the past, increasing emissions have correlated well with population (e.g., Khalil and Rasmussen, 1993). However, recent variations in the methane growth rate have challenged our understanding of the many factors that affect the sources of atmospheric methane. This abundance of factors complicates the resolution of past emissions and makes predictions of future $\mathrm{CH}_{4}$ emissions difficult.

Although methane emissions have climbed rapidly over the past four decades, the relative importance of agricultural sources may be declining, with non-agricultural sources related to fossil fuel use and waste disposal on the increase (Fig. 8). These sources are directly influenced by human activities and energy demand in ways that may not be easily predictable. In addition, they lack a well-resolved history of past emission trends to extrapolate into the future, a fact that greatly complicates methane emission prediction.

The magnitude of methane sources depends on numerous factors including human population, energy demand, crop yield, agricultural practices, land use area, temperature, precipitation, and other possible natural or anthropogenic influences not yet resolved, but that are expected to change significantly in the future. Methane concentrations are projected to con- tinue to rise well into the next century, as shown by the "business as usual" IS92a emission scenario (Fig. 9). The "low emissions" scenario, IS92c, also shows a continued increase in methane concentration for a number of decades. However, several of the new SRES (IPCC Special Report on Emissions Scenarios) emissions scenarios for $\mathrm{CH}_{4}$ that have been developed for the current ongoing IPCC assessment show reduced increases in emissions compared to the earlier scenarios (Fig. 10).

The majority of a projected increase in $\mathrm{CH}_{4}$ emissions is expected to be from human sources related to agriculture, waste, or energy. Projections of future emissions are additionally uncertain because of the high level of ignorance concerning potential biospheric feedbacks to climate change. Observations of the response of biogenic sources to seasonal changes in temperature have shown that emissions from wetlands, rice paddies, and other ecosystems may increase in response to increases in global mean temperature, producing a positive feedback to climate warming (e.g., Hameed and Cess, 1983; Lashof, 1989; Roulet et al., 1992; Neue and Roger, 2000; Boone, 2000; Bartlett and Harriss, 1993; Slanina et al., 1994; Panikov, 1999). With high levels of warming, methane stored in methane hydrates and clathrates could

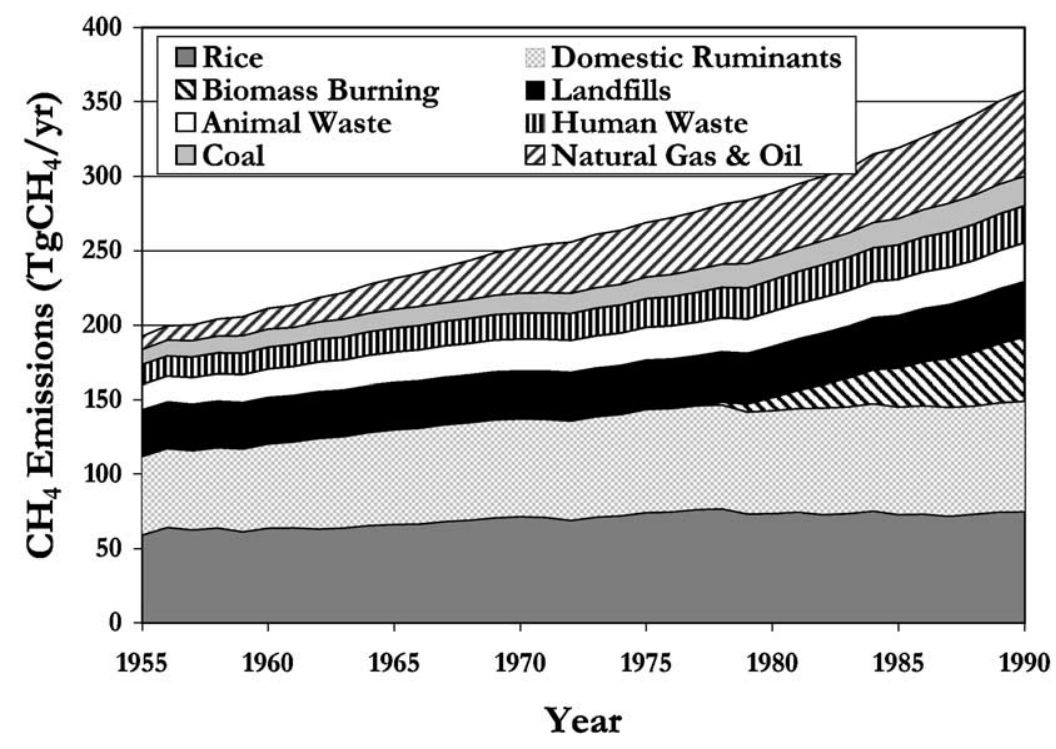

Fig. 8. Evolution of anthropogenic methane emissions, 1955-1990 (source: Hayhoe, 1997). 


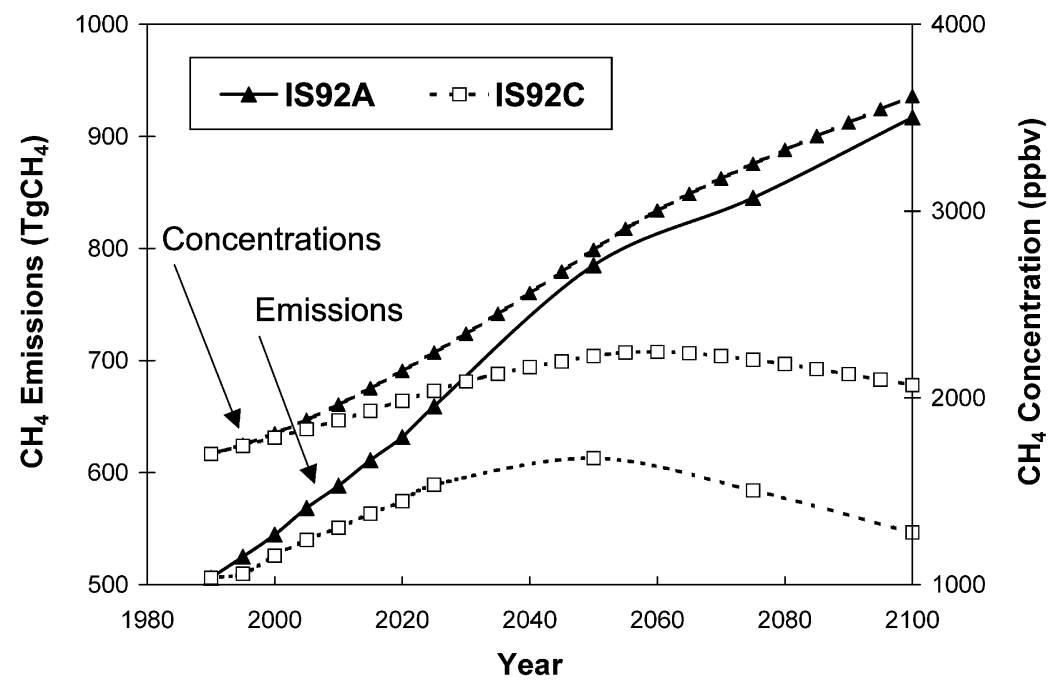

Fig. 9. Projected emissions and concentrations from IS92 scenarios A and C (source: IPCC, 1996; IPCC DDC CD-ROM).

also become destabilized, releasing large amounts of methane into the atmosphere (Nisbet, 1990a,b; MacDonald, 1990; Harvey and Huang, 1995), and increasing climate forcing.

Although methane concentrations are projected to continue to increase, it must be noted that recent decreases in the growth rate of methane have occurred without any controls on human emissions. If the declining trends in the growth rate over the past few decades had continued, rather than increasing as they have in the past 2 years, it is almost certain that a $\mathrm{CH}_{4}$ reduction strategy involving reductions of more than $5 \%$ of the anthropogenic source could have stabilized or even lowered atmospheric concentrations of meth-

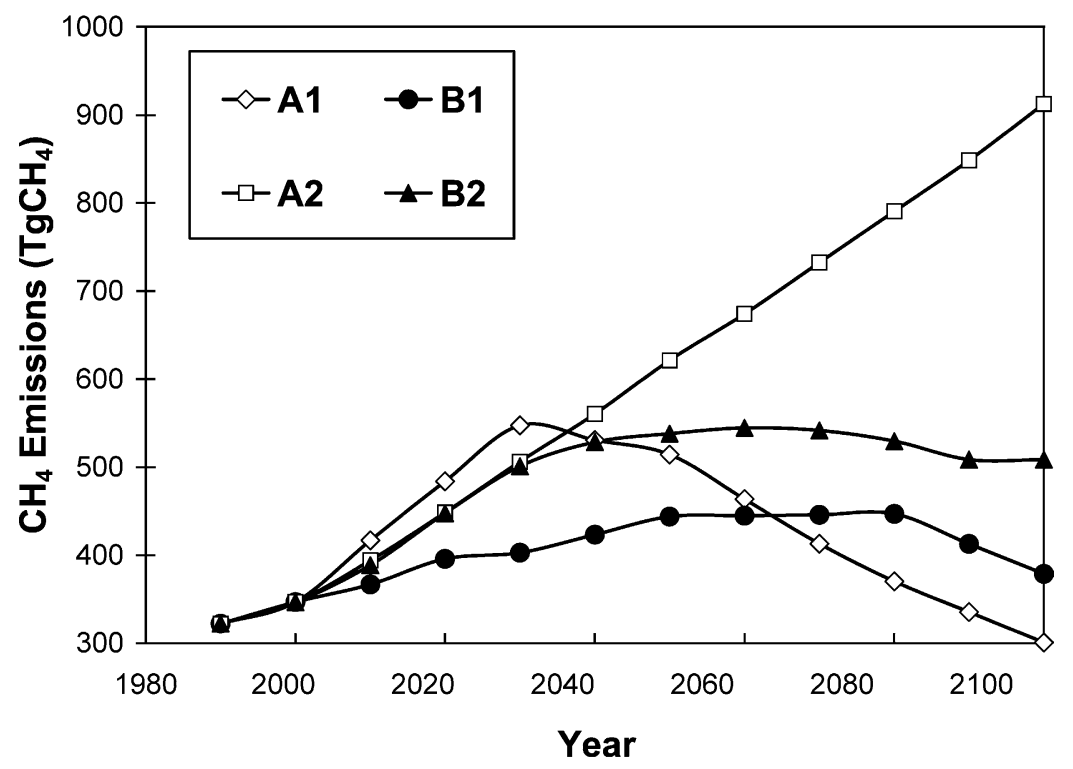

Fig. 10. New SRES emission projections for $\mathrm{CH}_{4}$ (source: IPCC DDC CD-ROM). 
ane (IPCC, 1996; Dlugokencky et al., 1998; Etheridge et al., 1998). However, as shown by Kheshgi et al. (1999), the trend in the concentration of methane is greatly dependent on any changes in the emissions of $\mathrm{CO}$ and $\mathrm{NO}_{x}$.

\subsubsection{Projections of $\mathrm{CH}_{4}$ sinks}

Concentrations of $\mathrm{OH}$, the main sink of atmospheric methane, are already closely linked with $\mathrm{CH}_{4}$ concentrations through the $\mathrm{CH}_{4}-\mathrm{CO}-\mathrm{OH}$ cycle. Most modelling studies conclude that $\mathrm{OH}$ concentrations have decreased by $10-30 \%$ since pre-industrial times, mainly due to increasing levels of $\mathrm{CH}_{4}$ and $\mathrm{CO}$ in the atmosphere (e.g., Thompson, 1992; Wang and Jacob, 1998). At the present time, $\mathrm{OH}$ concentration appears to be relatively steady or perhaps increasing, with the effects of increasing $\mathrm{CH}_{4}$ and $\mathrm{CO}$ balanced by increases in tropospheric $\mathrm{O}_{3}$ concentrations and in emissions of $\mathrm{NO}_{x}$ and NMHCs (Prinn et al., 1995; Krol et al., 1998; Karlsdottir and Isaksen, 2000). Although $\mathrm{OH}$ has no significant radiative effect, it is the primary oxidizing agent of the troposphere, responsible for the removal of methane, carbon monoxide, and NMHCs as well as numerous other pollutants and long-lived greenhouse gases. Changes in its concentration will therefore impact the abundances of many trace species, affecting local air pollution in addition to global chemistry and radiative properties of the atmosphere.

Projections of $\mathrm{OH}$ concentrations are highly uncertain - even more so than past changes. Future changes in atmospheric composition induced by trace gas emissions and climate change are expected to have major impacts on the rate of $\mathrm{OH}$ production and destruction. A number of modelling studies predict up to a $25 \%$ decrease in $\mathrm{OH}$ concentrations by 2050 (e.g., Thompson and Cicerone, 1986; Thompson et al., 1990; Pinto and Khalil, 1991; Lu and Khalil, 1991; Osborn and Wigley, 1994; Brasseur et al., 1998; Lelieveld et al., 1998; Wang and Jacob, 1998). This small range belies the major changes in $\mathrm{OH}$ production and destruction that are projected to occur. These changes balance each other out to a certain extent, particularly in the studies that predict little or no change in net $\mathrm{OH}$ levels.

$\mathrm{OH}$ loss rates are projected to increase in the future due to rising anthropogenic emissions of $\mathrm{CH}_{4}, \mathrm{CO}$, NMHCs, and other gases that are oxidized by $\mathrm{OH}$.
However, there are a number of additional factors that may balance net $\mathrm{OH}$ concentrations by increasing $\mathrm{OH}$ production.

$\mathrm{OH}$ is formed when $\mathrm{O}_{3}$ is photo-dissociated into $\mathrm{O}\left({ }^{1} \mathrm{D}\right)$, which in turn combines with water vapor to form two $\mathrm{OH}$ radicals, as shown by the following equations:

$\mathrm{O}_{3}+h v \rightarrow \mathrm{O}\left({ }^{1} \mathrm{D}\right)+\mathrm{O}_{2}$

$\mathrm{O}\left({ }^{1} \mathrm{D}\right)+\mathrm{H}_{2} \mathrm{O} \rightarrow \mathrm{OH}+\mathrm{OH}$

Emissions of $\mathrm{NO}_{x}$, an important component of local air pollution in urban areas, result in $\mathrm{O}_{3}$ formation that in turn increases $\mathrm{OH}$ production (Eq. (1)). Increasing $\mathrm{NO}_{x}$ emissions have been modeled to result in an increase in global $\mathrm{OH}$, and hence in the global methane sink (Fuglestvedt et al., 2000). A reduction in stratospheric ozone, such as that seen in recent decades, increases the flux of ultraviolet radiation reaching the troposphere, also promoting $\mathrm{OH}$ formation (Tang et al., 1998). As climate warms, the relationship between temperature and water vapor concentration may cause tropospheric water vapor levels to rise. This will also increase $\mathrm{OH}$ production (Eq. (2)). On the other hand, increases in tropospheric water vapor could also increase global mean cloud cover, which would decrease the flux of photons to the troposphere and decrease $\mathrm{OH}$ formation rates. Temperature increases also have an additional impact on temperature-dependent reaction coefficients, affecting many atmospheric reaction rates.

Although global average $\mathrm{OH}$ levels determine the average lifetime of $\mathrm{CH}_{4}$, several studies emphasize the importance of tropical $\mathrm{OH}$ levels in determining future changes in $\mathrm{OH}$ (Thompson et al., 1989; Crutzen and Zimmermann, 1991; Lelieveld et al., 1998). OH levels are highest in the tropics, with abundant water vapor and UV radiation ensuring high production rates. $\mathrm{CH}_{4}$ emissions from important sources such as rice cultivation, biomass burning, and domestic ruminants are also highest in the tropics. However, the tropics are also the region where the greatest changes in land use and industrialization are expected to occur in the future. What happens in this area will to a large part determine the future of $\mathrm{OH}$ concentrations in the atmosphere. 
The soil sink for methane, although substantially smaller than the $\mathrm{OH}$ sink, is also expected to change in the future. Methane oxidation in soil is sensitive to temperature and soil water content (Mancinelli, 1995; King, 1997), both of which may be altered by climate change. Perhaps more importantly, arable land has a much smaller $\mathrm{CH}_{4}$ uptake rate than untreated soils, particularly when treated with certain fertilizers (e.g., Boeckx et al., 1997; Mosier et al., 1997b, Powlson et al., 1997). Land use change, as forests and grasslands are converted to agriculture, has already decreased the soil sink, and is likely to continue to do so in the future (King, 1997; Mosier et al., 1997a). Even when converted back to its natural state, previously cultivated land continue to have a lower oxidation rate than untouched areas (e.g., Dobbie and Smith, 1996; Hudgens and Yavitt, 1997; Prieme et al., 1997). This apparent irreversibility of human impacts on $\mathrm{CH}_{4}$ oxidation rates has important implications for the future of land management strategies, as growing populations continue to exert pressure on natural ecosystems.

\section{Impact of $\mathrm{CH}_{4}$ on tropospheric and stratospheric chemistry}

\subsection{Methane and tropospheric chemistry}

As discussed previously, methane oxidation is one of the major reaction pathways affecting atmospheric concentrations of hydroxyl on a global scale. Depending on nitric oxide levels, methane oxidation can be either a production or destruction process for oddhydrogen $\left(\mathrm{OH}+\mathrm{HO}_{2}\right)$. Thus, different chemically coherent regions (Thompson et al., 1989) can be distinguished on the basis of concentrations of nitrogen oxides. Polluted (high $\mathrm{NO}_{x}$ ) environments where odd hydrogen is produced include the temperate zone of the Northern Hemisphere and planetary boundary layer of the tropics during the dry season. Unpolluted (low $\mathrm{NO}_{x}$ ) environments where odd hydrogen is destroyed include marine areas, the free troposphere over the tropics, and most of the Southern Hemisphere (e.g., Fishman et al., 1979; Crutzen, 1988; Cicerone and Oremland, 1988; WMO, 1991, 1995). Under warm, humid conditions, nitrogen oxide levels must be substantially higher to produce odd hydrogen, conditions that generally apply to the boundary layer. Most current modeling studies suggest that an increase in methane will decrease hydroxyl and increase ozone throughout the remainder of the troposphere.

The methane oxidation cycle is an important source of carbon monoxide, accounting for roughly a quarter of the carbon monoxide in the troposphere. Carbon monoxide concentrations are a great deal more variable than methane, due to its relatively short atmospheric lifetime (approximately 1-3 months) and because of the variety of natural and anthropogenic sources that contribute to its budget. These sources include fossil fuel combustion, biomass burning, and the oxidation of natural hydrocarbons emitted by vegetation (e.g., isoprene). As in the case of methane, the carbon monoxide oxidation cycle also depends on the levels of nitric oxide present in the atmosphere.

Based on the reaction sequences for methane, formaldehyde, and carbon monoxide in polluted as well as unpolluted environments, the effect of the complete oxidation of $1 \mathrm{~mol}$ of methane is an increase from 0.4 to $0.5 \mathrm{~mol}$ of odd hydrogen in the high $\mathrm{NO}_{x}$ case and a decrease from -3.5 to -3.9 mol of odd hydrogen in the low $\mathrm{NO}_{x}$ case. Correspondingly, the change in ozone for complete oxidation of methane is an increase of +3.6 to $3.8 \mathrm{~mol}$ for the high $\mathrm{NO}_{x}$ case and a decrease of -1.7 to $-1.8 \mathrm{~mol}$ for the low $\mathrm{NO}_{x}$ case. According to our calculations (Wuebbles et al., 2000), the catalytic subcycle involving the reaction of methylperoxyl $\left(\mathrm{CH}_{3} \mathrm{O}_{2}\right)$ with hydroperoxyl $\left(\mathrm{HO}_{2}\right)$ and the reaction of methyl peroxide $\left(\mathrm{CH}_{3} \mathrm{O}_{2} \mathrm{H}\right)$ with $\mathrm{OH}$ has a sizeable impact on the amount of odd hydrogen loss in the low $\mathrm{NO}_{x}$ case. Crutzen (1988) included this cycle in his results, whereas lower effects determined by Cicerone and Oremland (1988) did not include its effect. Our analyses of the resulting changes in oddhydrogen and ozone are substantially in agreement with Crutzen (1988) for both cases. The resultant destruction of odd hydrogen depends on the hydroxyl concentration, the methyl peroxide chemical reaction pathways, and the heterogeneous removal rates of important intermediate species.

Formaldehyde is an important intermediate in the removal processes of methane and other hydrocarbons as well as being important in the general chemical reactivity of the troposphere. Regardless of $\mathrm{NO}_{x}$ levels, methane oxidation is responsible for the formation of 
much of the formaldehyde in the atmosphere. Based on the estimate of Lowe and Schmidt (1983), the formaldehyde production rate is on the order of $10^{14} \mathrm{~g} /$ year. The other major photochemical precursors of formaldehyde consist of nonmethane hydrocarbons and higher aldehydes. The non-methane hydrocarbons are emitted from natural and anthropogenic sources while the higher aldehydes are produced by in situ photochemistry. There are appreciable anthropogenic sources of formaldehyde as well (e.g., automobile exhaust).

In order to analyze the photochemical mechanisms that produce formaldehyde, we must distinguish between different regions on the basis of $\mathrm{NO}_{x}$ levels. In the methane oxidation mechanism under low $\mathrm{NO}_{x}$ conditions, methyl peroxide reacts with $\mathrm{OH}$ to produce formaldehyde. Since methyl peroxide has a long lifetime against photolysis, heterogeneous processes (which occur on aerosols) can serve as a loss mechanism for this species in unpolluted environments. This implies that formaldehyde production is controlled by aerosol concentrations in remote regions. However, in polluted environments, formaldehyde formation does not involve methyl peroxide. In this case, it would be regulated by nitric oxide concentrations because methylperoxyl is reduced to methoxyl. Methoxyl then reacts with oxygen to produce formaldehyde.

Once it is generated, formaldehyde is quickly destroyed under direct insolation. During the daytime, photolysis is the dominant loss process for formaldehyde in the remote troposphere, while in polluted atmospheres, reactions with hydroxyl and hydroperoxyl are comparable to photolytic degradation. At night, the only appreciable formaldehyde consumption is by reaction with nitrate radical $\left(\mathrm{NO}_{3}\right)$ but this is slow in comparison to the daytime reactions with hydroxyl and hydroperoxyl.

Approximately $10 \%$ of the ozone in the atmosphere is located in the troposphere. The downward transport of ozone from the stratosphere traditionally was thought to be the major source of tropospheric ozone (Crutzen, 1988 and references therein). It is now generally accepted that the net tropospheric photochemical production of ozone is of similar magnitude to the downward transport source (e.g., Fishman et al., 1979; Fishman, 1985; WMO, 1985, 1995; Isaksen, 1988; Penkett, 1988; Hough and Derwent, 1990).
Nitrogen dioxide photolysis is by far the primary photochemical mechanism for producing ozone in the troposphere. This implies that the generation rate is roughly proportional to the concentration of nitric oxide. High concentrations of $\mathrm{NO}_{x}$ over the continental boundary layer signify that this region is likely a net source of ozone. Increases in $\mathrm{NO}_{x}$ emissions may lead to further ozone increases, especially in the tropics. However, the magnitude of odd oxygen $\left(\mathrm{O}+\mathrm{O}\left({ }^{1} \mathrm{D}\right)+\mathrm{O}_{3}\right)$ production is ultimately limited by the supply of $\mathrm{CO}, \mathrm{CH}_{4}$, and NMHCs. The oxidation of $1 \mathrm{~mol}$ of CO can form $1 \mathrm{~mol}$ of ozone. In contrast, the complete oxidation of a mole of methane can produce 3-4 mol of ozone. Because there is insufficient $\mathrm{NO}_{x}$ present in the background troposphere, it is estimated that only about $10 \%$ of the potential tropospheric ozone production is being realized.

\subsection{Methane and stratospheric chemistry}

Although $\sim 90 \%$ of total emissions of methane are consumed by reaction with tropospheric hydroxyl and about $5 \%$ by soil uptake (IPCC, 1995), the remaining $5 \%$ of methane flux, on average about $27 \mathrm{TgCH}_{4}$ year (Gettelman et al., 1997), enters the stratosphere.

In the stratosphere and higher layers of the atmosphere, the reaction with $\mathrm{OH}$ continues to be the dominant sink for $\mathrm{CH}_{4}$, but reactions with chlorine atoms and excited oxygen atoms are also important. Reactions with chlorine atoms account for about $9 \%$ of the methane loss in these regions (Brenninkmeijer et al., 1995). Measurements also suggest that the increased oxidation of methane resulting from increasing concentrations of chlorine in the stratosphere has led to enhanced production of stratospheric $\mathrm{OH}$ (e.g., Burnett and Burnett, 1995).

In order to put the role of methane in stratospheric chemistry into context, it is useful to first discuss the importance of ozone and the changes occurring in its distribution. Changes in the distribution and amount of ozone in the global troposphere and stratosphere have received much attention over the past few decades. Much of the concern about ozone has centered on the importance of ozone as an absorber of ultraviolet radiation, as its concentrations determine the amount of ultraviolet radiation reaching the Earth's surface. Ozone is also a greenhouse gas and can influence climate. 
Approximately $90 \%$ of the ozone in the atmosphere is contained in the stratosphere. In the stratosphere, the production of ozone begins with the photodissociation of oxygen $\left(\mathrm{O}_{2}\right)$ at ultraviolet wavelengths less than $242 \mathrm{~nm}$. This reaction produces two ground-state oxygen atoms that can react with oxygen to produce ozone. Since an oxygen atom is essentially the same as having an ozone molecule, it is common to refer to the sum of the concentrations of ozone and oxygen atoms (both ground state and excited state) as odd-oxygen. The primary destruction of odd-oxygen in the stratosphere comes from catalytic mechanisms involving various free radical species. Nitrogen oxides, chlorine oxides, and hydrogen oxides participate in catalytic reactions that destroy odd-oxygen.

Chlorine and bromine catalytic mechanisms are particularly efficient in destroying ozone. These mechanisms have been the subject of much study due to their effects on concentrations of stratospheric ozone over recent decades, particularly since levels of reactive chlorine in the stratosphere have been growing rapidly over this time as a result of emissions of trichlorofluoromethane $\left(\mathrm{CFCl}_{3}\right)$, difluorodichloromethane $\left(\mathrm{CF}_{2} \mathrm{Cl}_{2}\right)$, bromine-containing halons, and other halocarbons. The chlorine- and bromine-catalytic cycles can turn over thousands of times before the catalyst is converted to a less reactive form. Because of this cycling, relatively small concentrations of reactive chlorine or bromine can have a significant impact on the amount and distribution of ozone in the stratosphere. The total amount of chlorine in the current stratosphere is $\sim 3$ ppbv, much of which is in the form of less reactive compounds like hydrochloric acid $(\mathrm{HCl})$.

Methane plays an important role in the chlorine chemistry of the stratosphere, serving both as a source and a sink in key reactions affecting reactive chlorine. The direct reaction of methane with a chlorine atom is the primary source of hydrochloric acid, the main chlorine reservoir species. However, $\mathrm{OH}$ produced through the oxidation of methane in the stratosphere can react with the hydrochloric acid to return the chlorine atom, thus reinitiating the chlorine catalytic mechanism. Although the most important effect of increasing methane is the increasing conversion of reactive chlorine to $\mathrm{HCl}$, there is also a smaller increase in the conversion rate of reactive chlorine to $\mathrm{HCl}$. Thus, increasing chlorine tends to slow down the effects of chlorine on ozone. Conversely, controls on methane could exacerbate the effects of chlorine on ozone by slowing down the conversion to $\mathrm{HCl}$. It should be noted that a similar mechanism is not important for bromine because of the slow reactivity of $\mathrm{Br}$ with $\mathrm{CH}_{4}$.

In addition to being involved in the reaction taking reactive chlorine to the less reactive $\mathrm{HCl}$, methane has several other effects on stratospheric ozone. Hydrogen oxides produced from the dissociation of methane can react catalytically with ozone, particularly in the upper stratosphere. In the lower stratosphere, the primary effect of these hydrogen oxides is to react with nitrogen oxides and reactive chlorine, reducing the effectiveness of associated ozone destruction catalytic cycles. The hydrogen oxides at these altitudes can also react catalytically to destroy ozone.

\subsection{Model-calculated effects on ozone}

Changing atmospheric concentrations of a number of compounds, including methane, are currently affecting the distribution of ozone in the troposphere and stratosphere. A number of research studies have used numerical models to examine the combined effects on ozone from the increases in concentrations of methane and the other gases described in the previous section (e.g., Wuebbles et al., 1983; Stordal and Isaksen, 1987; WMO, 1985, 1989, 1995, 1999). When combined with the effects of other trace gas emissions, it is difficult to evaluate the specific contribution of methane to the observed and projected ozone trends. For this reason, it is useful to examine studies that have only considered the effects of increasing methane on ozone.

Numerical models of atmospheric chemical and physical processes generally find that increasing methane concentrations result in a net ozone production in the troposphere and lower stratosphere and net ozone destruction in the upper stratosphere (Owens et al., 1982, 1985; WMO, 1985, 1991, 1995; Isaksen and Stordal, 1986). The net effect from these calculations has been that methane by itself causes a net increase in ozone. For a doubling of the methane concentration (early papers studied $\mathrm{CH}_{4}$ increases from 1.6 to 3.2 ppmv, while recent analyses assume a globally-averaged change from 1.7 to $3.4 \mathrm{ppmv}$ ), published effects on the calculated change in total ozone range from $+0.3 \%$ (Prather in WMO, 1985) to $+4.3 \%$ (Owens et al., 1985). With radiative feedback effects included (allowing temperature changes in the 
stratosphere), the published model results tend to be in the upper end of this range (Owens et al., 1985; WMO, 1985; Isaksen and Stordal, 1986).

The effects on tropospheric and stratospheric ozone for a doubling of the methane surface concentrations from the UIUC zonally-averaged model (Wuebbles et al., 1998; Rahmes et al., 1998) are given in Fig. 11 (change in total ozone as a function of latitude and season) and Fig. 12 (change in ozone with altitude and latitude for July). This two-dimensional model analysis, which includes radiative feedbacks, gives a 3.4\% increase in globally-averaged total ozone from a doubling of methane surface concentrations.

Calculations of the effect of methane increases on stratospheric ozone give a small percentage increase in the lower stratosphere, a larger increase near $40 \mathrm{~km}$ altitude, and a decrease in ozone above $45 \mathrm{~km}$. As mentioned earlier, the hydrogen oxides produced by methane oxidation affect the efficiency of the nitrogen oxide and chlorine oxide catalytic ozone destruction mechanisms. However, the effect of methane in the lower stratosphere will depend on the efficiency of the nitrogen oxide catalytic cycle; if the amount of reactive odd nitrogen is reduced, then the additional hydrogen oxides from methane could destroy ozone in this region. Additional heterogeneous reactions involving $\mathrm{N}_{2} \mathrm{O}_{5}, \mathrm{BrONO}_{2}$ and $\mathrm{ClONO}_{2}$ reduce the efficiency of the nitrogen oxide catalytic cycle, and increased $\mathrm{HO}_{x}$ from increases in atmospheric methane has a larger effect on the lower stratosphere as compared to previous calculations (Wuebbles et al., 2000). In the upper stratosphere, the additional hydrogen oxides react catalytically with ozone, causing models to find a decrease in ozone at these altitudes.

The version of the model used here includes convective mixing processes in the troposphere and also includes a number of non-methane hydrocarbons. The change in column ozone resulting from a calculation

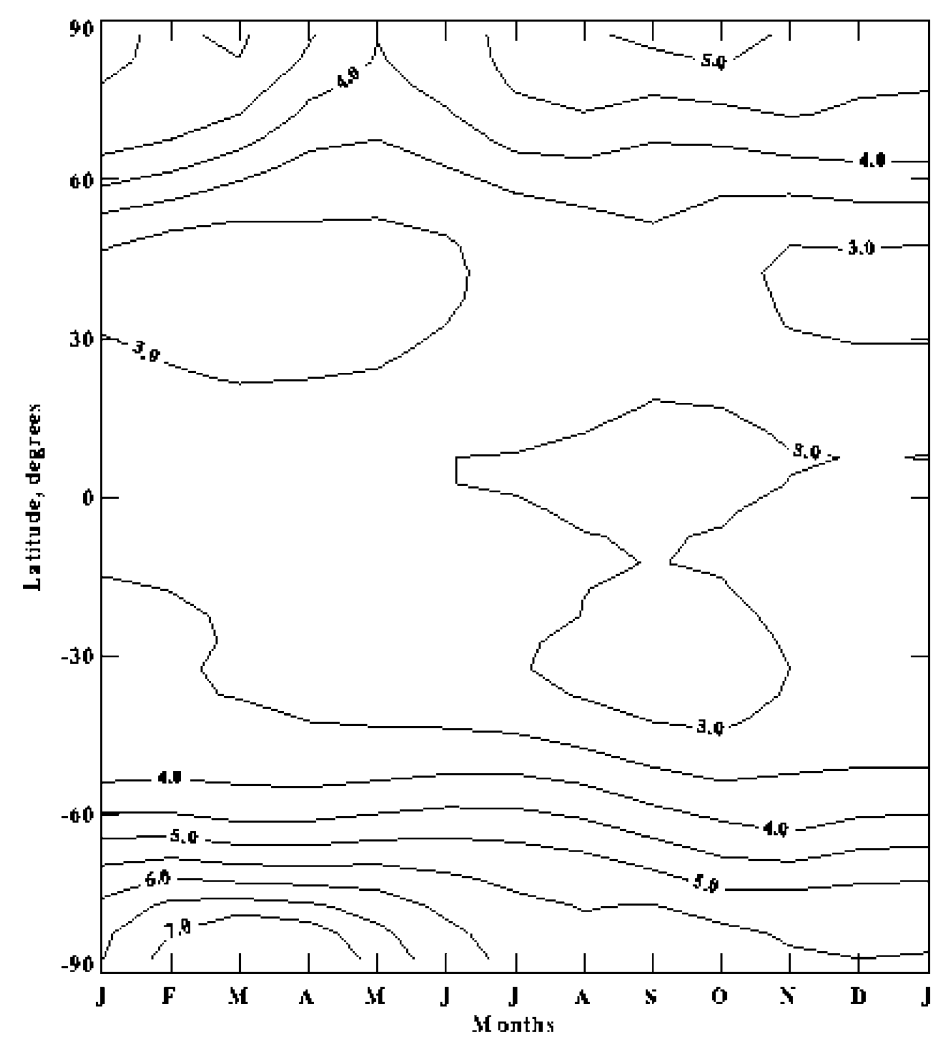

Fig. 11. Calculated percentage change of total ozone for a doubling in the concentration of atmospheric methane from 1.7 to 3.4 ppmv. Based on the UIUC two-dimensional chemical-transport model. 


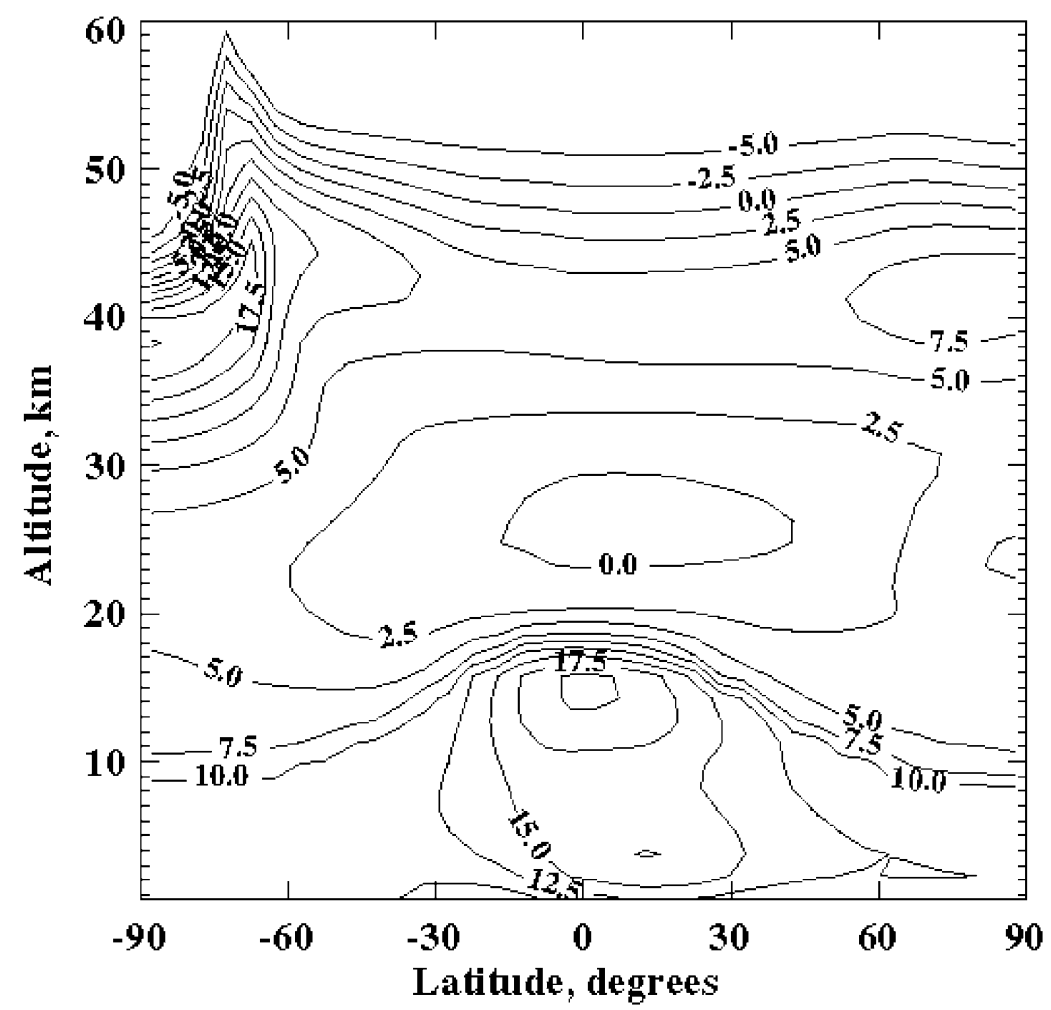

Fig. 12. Calculated percentage change of local ozone in July for a doubling in the concentration of atmospheric methane as in Fig. 10.

for doubling $\mathrm{CH}_{4}$ without NMHCs compared to a simulation with NMHCs is an increased response ranging from 3\% to $8 \%$ larger than that when the effect of NMHCs is included. The effect on the Southern Hemisphere is negligible, as there are no significant nonNMHC emissions from this region. Thus, the model response is damped for a doubling of methane surface concentration when non-methane hydrocarbons are included in the model. This damping results from the additional sources of reactive oxides available in the lower troposphere from hydrocarbons sources. The current model gives a feedback factor, defined as the percentage change in $\mathrm{OH}$ for a $1 \%$ change in $\mathrm{CH}_{4}$ of $0.32 \%$, which is well within the range of those calculated in WMO (1995).

\subsection{Upper atmospheric water vapor}

The spatial distribution of water vapor in the troposphere is primarily determined by evaporation, condensation and transport processes. Very little of the tropospheric water vapor penetrates into the stratosphere. The mechanisms limiting the transport of tropospheric water vapor into the stratosphere are still not well understood. Concentrations of water vapor increase with altitude in the stratosphere, from $3 \mathrm{ppmv}$ in the lower stratosphere to about $6 \mathrm{ppmv}$ in the upper stratosphere. This increase in concentration with altitude occurs as a result of the oxidation of methane.

Methane oxidation reactions produce roughly two mol of water vapor for each mole of methane that is destroyed. Stratospheric water vapor concentrations should increase as concentrations of methane increase. Since methane concentrations have increased from about $0.7 \mathrm{ppmv}$ in the pre-industrial atmosphere to the current concentration of $1.7 \mathrm{ppmv}$, this implies that upper stratospheric water vapor concentrations have increased by roughly 2 ppmv over this time period. In actual fact, the increase in water vapor should be somewhat less than this due to methane reactivity with chlorine and oxygen atoms. Both modeling and data analysis studies (e.g., Le Texier 
et al., 1988; Hansen and Robinson, 1989; Randel et al., 1998; Zoger et al., 1999) are in agreement with this conclusion, indicating that the overall stratospheric water vapor yield from methane is slightly less than two. A doubling of methane surface concentration in the UIUC two-dimensional model of the global atmosphere gives an increase in the amount of water vapor at the stratopause, near $50 \mathrm{~km}$, of approximately $40 \%$ or about 3 ppmv.

Increasing methane concentrations should also be leading to increasing concentrations of water vapor in the mesosphere. In conjunction with carbon dioxide, increasing methane concentrations should also lead to cooler temperatures in the stratosphere, mesosphere, and thermosphere (WMO, 1985, 1989; Brasseur and Hitchman, 1988; Roble and Dickinson, 1989). With the increase in water vapor and the cooler temperatures, there is the potential for increased occurrences of noctilucent clouds near the mesopause (Thomas et al., 1989). Roble and Dickinson (1989) also point out that other changes in mesospheric and thermospheric composition should occur due to both the cooler temperatures and direct chemical effects from increased concentrations of methane and carbon dioxide. In addition, exospheric hydrogen will increase with increasing methane (Ehhalt, 1986).

\section{Impact of methane on climate}

\subsection{Direct effects}

In the past, the concern that human activities may be affecting global climate has largely centered around carbon dioxide because of its importance as a greenhouse gas and also because of the rapid rate at which its atmospheric concentration has been increasing. However, it is clear that other greenhouse gases have also significantly affected climate over the past few centuries. Rising methane concentrations are a major contributor to the increase in radiative forcing since pre-industrial times, second only to carbon dioxide. The combined effect of methane and the other greenhouse gases has been to approximately double the overall increase in the greenhouse radiative forcing on climate relative to that from $\mathrm{CO}_{2}$. Like other greenhouse gases, methane absorbs infrared radiation (also called longwave or terrestrial radiation) emitted by the relatively warm planetary surface and emits radiation to space at the colder atmospheric temperatures, leading to a net trapping of infrared radiation in the atmosphere. This is called the greenhouse effect. The balance between the absorbed solar radiation and the emitted infrared radiation determines the net radiative forcing on climate.

Although its atmospheric abundance is less than $0.5 \%$ that of carbon dioxide, methane is an important greenhouse gas. Donner and Ramanathan (1980) calculated that the presence of methane at current levels causes the globally-averaged surface temperature to be about $1.3 \mathrm{~K}$ higher than it would be without methane. On a molar basis, an additional mole of methane in the current atmosphere is about 24 times more effective at absorbing infrared radiation and affecting climate than an additional mole of carbon dioxide (WMO, 1999). Correspondingly, on a mass basis, an additional kilogram of methane is about 66 times more effective as a greenhouse gas than a kilogram of carbon dioxide. It should be noted that the actual lifetime of carbon dioxide in the atmosphere is much longer than the atmospheric lifetime of methane (IPCC, 1990, 1996). However, it should also be recognized that the dissociation of methane eventually produces carbon dioxide, leading to additional climatic forcing from methane emissions from fossil sources. ${ }^{5}$

The strongest bands for absorption by methane in the infrared are in the short wavelength edge of the 'window region' $(\sim 7-13 \mu \mathrm{m}$, where there is little absorption by $\mathrm{H}_{2} \mathrm{O}$ or $\mathrm{CO}_{2}$ ). The most important infrared spectral feature of methane is the $7.66 \mu \mathrm{m}$ $\left(1306 \mathrm{~cm}^{-1}\right)$ absorption band. Due to saturation of the line cores for methane and emissions from the pressure-broadened Lorentz line wings, radiative forcing from methane increases approximately as the square root of its concentration (IPCC, 1990; Wigley, 1987). Overlap with absorption by water vapor and other species (particularly nitrous oxide) also affects the efficiency of methane absorption.

Wang et al. (1991) show that the greenhouse radiative forcing for methane has different spatial effects on climate than carbon dioxide, and that methane needs to be accounted for explicitly when attempting

\footnotetext{
5 The oxidation of methane from biogenic sources also results in $\mathrm{CO}_{2}$ production, but the forcing of $\mathrm{CO}_{2}$ from these sources has already been taken into account as part of the carbon cycle.
} 
to predict the climate response to increasing concentrations of greenhouse gases. Calculations with threedimensional global climate models (GCMs) are beginning to consider the explicit effects of methane on climate. Hansen et al. (1988) and Wang et al. (1991) have explicitly considered the effects of methane in GCM studies, while many other studies have included methane only through accounting for its radiative forcing through use of an increase in carbon dioxide as a proxy.

Increasing concentrations of methane are thought to be a significant fraction of the increase in radiative forcing from greenhouse gases over the last two centuries. IPCC (1996) calculated that the direct radiative effect of the increase in methane since the mid-1700s has produced a radiative forcing increase of $0.47 \mathrm{~W} \mathrm{~m}^{-2}$. $^{6}$ This is about $19 \%$ of the total change in radiative forcing due to $\mathrm{CO}_{2}$ and other greenhouse gases over this time period. ${ }^{7}$ Inclusion of indirect effects of methane increases on stratospheric water vapor, ozone, and carbon dioxide (see next section) could increase this percentage by at least $10-35 \%$ (e.g., IPCC, 1995; Bruhl, 1993; Lelieveld et al., 1993, 1998; Fuglestvedt et al., 1996).

A recent analysis of the radiative forcing for methane (Jain et al., 2000), accounting for the latitudinal and seasonal variations in methane concentrations, calculates a larger radiative forcing contribution from methane than earlier studies. The globally- and annually-averaged radiative forcing based on the new calculations was $4.67 \times 10^{-4} \mathrm{~W} \mathrm{~m}^{-2}$ for a $1-\mathrm{ppb}$ change in methane, compared to $3.7 \times 10^{-4} \mathrm{~W} \mathrm{~m}^{-2}$ in IPCC (1996). The estimated change in radiative forcing from pre-industrial times to 1992 was $0.55 \mathrm{~W}$ $\mathrm{m}^{-2}$ compared to 0.47 in IPCC (1996). Minschwaner et al. (1998) also determined a radiative forcing for methane from 1750 to 1992 of $0.55 \mathrm{~W} \mathrm{~m}^{-2}$ based on the observed distribution of methane from the Upper Atmosphere Research Satellite.

Over the last decade, increases in atmospheric methane concentration are calculated to have increased

\footnotetext{
${ }^{6}$ Climate models indicate that the $4 \mathrm{~W} \mathrm{~m}^{-2}$ forcing associated with a doubling of $\mathrm{CO}_{2}$ from 300 to 600 ppmv would give approximately a $1.5-$ to $4.5-\mathrm{K}$ increase in surface temperature.

${ }^{7}$ Other research studies have found similar percentages for the effect of methane over this period: e.g., Rodhe (1990) derived 15\%, while Hansen et al. (1989) and MacKay and Khalil (1991) calculated $\sim 22 \%$.
}

radiative forcing by about $0.06 \mathrm{~W} \mathrm{~m}^{-2}, 11 \%$ of the total increase in radiative forcing from greenhouse gases over this time period (WMO, 1999). ${ }^{8}$

Various studies have evaluated the potential effects of a doubling of methane concentrations on radiative forcing and surface temperature using radiative-convective models. For an increase from 1.6 to $3.2 \mathrm{ppmv}$, resulting increases in surface temperature range $0.2-$ $0.3 \mathrm{~K}$ (Owens et al., 1985; Ramanathan et al., 1987; MacKay and Khalil, 1991; IPCC, 1995), with the differences in model results primarily relating to uncertainties in the band strengths for methane infrared absorption. For a doubling from 1.7 to $3.4 \mathrm{ppmv}$, Owens et al. (1985) calculated a direct $0.34 \mathrm{~K}$ increase in surface temperature, along with an additional 0.26 $\mathrm{K}$ due to indirect effects from methane-induced effects on carbon dioxide and ozone. For a $25 \%$ increase in methane concentrations, Ramanathan et al. (1985) determine a $0.08-\mathrm{K}$ increase in surface temperature when overlap with the radiative absorption with other greenhouse gases is included, and a $0.19-\mathrm{K}$ increase in surface temperature without overlap.

Other modeling studies have included increasing methane concentrations in studies evaluating scenarios for potential future changes in radiative forcing and global temperatures (Wang and Molnar, 1985; Ramanathan et al., 1985, 1987; WMO, 1985; Dickinson and Cicerone, 1986; Wang et al., 1986; Wigley, 1987; Hansen et al., 1988, 1989; IPCC, 1990, 1995, 1996). In Table 2 , the change in radiative forcing due to increasing methane is compared to the total change in forcing due to all greenhouse gases for three IPCC emission scenarios (high, medium and low) (IPCC, 1996). These more recent scenarios generally show a somewhat increased role for methane in determining future radiative forcing. However, these studies do not consider the significant indirect effects from chemical interactions as discussed next.

\subsection{Indirect effects}

In addition to its direct radiative forcing effect on climate, methane can also influence climate indirectly through chemical interactions affecting other radia-

\footnotetext{
${ }^{8}$ Note that these estimates ignore the effects on radiative forcing due to changes in global ozone and aerosols over this time period.
} 
Table 2

Change in radiative forcing $\left(\mathrm{W} \mathrm{m}^{-2}\right)$ due to increasing methane, as compared to total change in forcing due to all greenhouse gases. Radiative forcing given by IPCC (1996) for their high (IS92e), medium (IS92a), and low (IS92c) emission scenarios

\begin{tabular}{|c|c|c|c|c|c|c|c|c|c|}
\hline \multirow[t]{3}{*}{ Time period } & \multicolumn{9}{|c|}{ Scenarios } \\
\hline & \multicolumn{3}{|c|}{ IS92a } & \multicolumn{3}{|c|}{ IS92c } & \multicolumn{3}{|c|}{ IS92e } \\
\hline & $\mathrm{CH}_{4}$ & All & $\%$ & $\mathrm{CH}_{4}$ & All & $\%$ & $\mathrm{CH}_{4}$ & All & $\%$ \\
\hline $1765-2025$ & 0.66 & 4.01 & 16.4 & 0.59 & 3.63 & 16.2 & 0.69 & 4.31 & 16.0 \\
\hline $1765-2050$ & 0.83 & 5.37 & 15.4 & 0.65 & 4.37 & 14.9 & 0.89 & 6.12 & 14.5 \\
\hline $1990-2025$ & 0.19 & 1.61 & 11.8 & 0.12 & 1.23 & 9.7 & 0.22 & 1.91 & 11.5 \\
\hline $1990-2050$ & 0.36 & 2.97 & 12.1 & 0.18 & 1.97 & 9.1 & 0.42 & 3.72 & 11.3 \\
\hline
\end{tabular}

tively important gases. Methane is an important influence on concentrations of hydroxyl, the primary tropospheric oxidizing agent, which in turn determines the rate at which methane is removed from the atmosphere. Methane oxidation is also a significant source of tropospheric and stratospheric ozone, stratospheric water vapor, and its eventual final product, carbon dioxide.

Resolving changes in tropospheric $\mathrm{OH}$ due to $\mathrm{CH}_{4}$ emissions is difficult because of uncertainties associated with modeling the non-linear relationships in the $\mathrm{CH}_{4}-\mathrm{CO}-\mathrm{OH}$ cycle. Increases in the response time of methane to a perturbation can result in a much larger apparent lifetime for the perturbed methane than the overall atmospheric lifetime of methane (Prather, 1994; IPCC, 1995, 1996). Tropospheric OH concentrations are expected to change in the future due to increases in $\mathrm{CH}_{4}$ as well as other trace gases such as $\mathrm{CO}, \mathrm{NO}_{x}, \mathrm{O}_{3}, \mathrm{NMHCs}$ and water vapor. Depending on the emission scenario examined, trace gas emissions can either lengthen or shorten the lifetime of $\mathrm{CH}_{4}$, resulting in a positive or negative indirect effect (Hayhoe et al., 2000; Bruhl, 1993; Lelieveld et al., 1993, 1998).

Changes in tropospheric ozone associated with increasing methane are the most important indirect effect, capable of adding $19 \pm 12 \%$ to the direct radiative forcing from methane (IPCC, 1995; based on UIUC and other two-dimensional model studies). The large remaining uncertainty is associated with the overall uncertainties in understanding the processes affecting ozone in the troposphere.

Methane oxidation in the stratosphere is an important source of water vapor. Although the concentration of water vapor in the stratosphere is several orders of magnitude smaller than tropospheric concentrations, at the low temperatures found in the lower stratosphere, relatively small changes in water vapor levels can significantly impact radiative forcing. Therefore, an increase in stratospheric water vapor concentrations resulting from increasing methane concentrations will enhance the greenhouse effect, and provide a positive indirect effect that will enhance the direct radiative forcing from the added methane. While earlier studies assuming a mixing ratio increase in methane suggested that the increase in water vapor could enhance the radiative forcing by as much as 30\% (IPCC, 1990), more recent studies (Lelieveld and Crutzen, 1991, 1992; Bruhl, 1993; Lelieveld et al., 1993; Hauglustaine et al., 1994; IPCC, 1995) using flux boundary condition changes in methane have shown the effect of the water vapor increase to be much smaller, $4-5 \%$ of the total direct radiative forcing from methane.

Increasing water vapor could also lead to an increased amount of polar stratospheric clouds. Ramanathan (1988) showed that both water and ice clouds, when formed at cold lower stratospheric temperatures, are extremely efficient in enhancing the atmospheric greenhouse effect. He also noted that there is a distinct possibility that large increases in future methane may lead to a surface warming that increases nonlinearly with the methane concentration.

Finally, methane oxidation eventually ends in the production of carbon dioxide, one of the most important greenhouse gases. However, about $500 \mathrm{Tg} /$ year of methane are destroyed by reaction with hydroxyl and converted to carbon dioxide, accounting for production of only $380 \mathrm{TgC} /$ year as carbon dioxide; in contrast, emissions of carbon dioxide from anthropogenic fossil fuel use and cement manufacturing are $\sim 6000 \mathrm{TgC} /$ year. In addition, $\mathrm{CO}_{2}$ produced by the oxidation of methane from biogenic sources is already included in the carbon cycle budget; only $\mathrm{CO}_{2}$ from methane emitted by fossil fuel sources contributes to the indirect effect.

\subsection{Global warming potentials}

Global Warming Potentials (GWPs) have been developed as an analysis tool for policy makers to assist in the evaluation of possible policy actions related to greenhouse gas controls. The Kyoto Protocol uses GWPs to weight emissions of the six green- 
house gases that can be included in national emission reduction strategies (UNFCCC, 1997). Based on emission reductions required under the Kyoto Protocol, we recently analyzed greenhouse gas abatement scenarios for the U.S. (Hayhoe et al., 1999). Using a 100-year GWP for methane, as specified in the Protocol, our results indicate that the cost of achieving a reduction of $650 \mathrm{GtC}_{\mathrm{eq}}$ by 2010 would be reduced by at least $25 \%$ if methane were included in a previously $\mathrm{CO}_{2}$ only strategy.

The GWP of a greenhouse gas is defined as the time-integrated commitment to climatic forcing from the instantaneous release of a kilogram of the gas relative to the climatic forcing from the release of $1 \mathrm{~kg}$ of carbon dioxide, and is generally calculated for constant background concentrations. Published GWPs are derived for integration periods from 20 to 500 years, with the 100-year values generally thought to provide a balanced representation of the various time horizons for climatic response. Under this measure, the latest 100-year GWP for methane, including both direct and indirect effects, is $24 \pm 7.5$ (WMO, 1999; IPCC, 1995), compared to 1.0 for carbon dioxide. The GWPs from IPCC (1996) for direct plus indirect effects from methane for the 20- and 500-year integrations are $62 \pm 20$ (64 in WMO, 1999) and 7.5 \pm 2.5 , respectively. As shown in IPCC $(1990,1995)$, indirect effects can more than double the direct methane GWP value (see also Fuglestvedt et al., 1996; Lelieveld et al., 1998). Additional uncertainties are introduced by the assumption of constant background concentrations over the length of the integration. Projected changes in atmospheric concentrations of $\mathrm{CH}_{4}$ and other trace gases such as $\mathrm{OH}, \mathrm{CO}$ and $\mathrm{NO}_{x}$ affect the removal rate of $\mathrm{CH}_{4}$ and hence its GWP (Hayhoe et al., 2000). Uncertainties in GWPs of methane and other important greenhouse gases in turn affect their optimal contribution to emission reductions and hence to the prevention of climate change.

\section{Summary and conclusions}

The atmospheric concentration of methane has increased dramatically over the last century and continues to increase. While budget and isotopic analyses have confirmed the causal role of human activities in this increase, significant uncertainties remain in un- derstanding the factors that affect emissions from various sources and how these will change over time. Uncertainties in how the sources and sinks of methane will change in the future limit our ability to develop meaningful climate change policies aimed at controlling methane emissions.

The 1998 increase in the growth rate of methane has renewed the debate about future levels of methane. This increase could just be a short-lived anomaly. However, if this increase is the first sign of one of the most important biogenic feedbacks to climate change - the response of wetlands to the increases in global temperatures - this raises urgent questions concerning the magnitude of the response of methane concentrations to the much larger increases in global temperatures projected to occur over the next century.

More research is needed to fully understand the growth rate in methane and its future projection. More complete analyses will require increased coordination between programs measuring atmospheric abundances and isotopic ratios, and modelling efforts that couple biospheric and oceanic biogeochemistry with atmospheric processes.

\section{Acknowledgements}

This study was supported in part by the U.S. Environmental Protection Agency and by the National Aeronautics and Space Administration's Atmospheric Chemistry Modeling and Analysis Program.

\section{References}

Bains, S., Corfield, R., Norris, R., 1999. Mechanisms of climate warming at the end of the Paleocene. Science 285, 724-727.

Barns, D.W., Edmonds, J.A., 1990. An Evaluation of the relationship between the production and use of energy and atmospheric methane emissions. U.S. Dept. of Energy, Carbon Dioxide Research Program, TR047, 223 pp.

Bartlett, K., Harriss, R., 1993. Review and assessment of methane emissions from wetlands. Chemosphere 26, 261-320.

Bates, T.S., Kelly, K.C., Johnson, J.E., Gammon, R.H., 1996. A reevaluation of the open ocean source of methane to the atmosphere. J. Geophys. Res. 101, 6953-6961.

Bazhin, N., 1994. Sources and sinks of methane on the territory of the former USSR. Pure Appl. Chem. 66, 188-191.

Beck, L.L., Piccot, S.D., Kirchgessner, D.A., 1993. Industrial sources. In: Khalil, M. (Ed.), Atmospheric Methane: Sources, Sinks and Role in Global Change. Springer-Verlag, New York, NY, pp. $341-399$ 
Bekki, S., Law, K., 1997. Sensitivity of the atmospheric $\mathrm{CH}_{4}$ growth rate to global temperature changes observed from 1980 to 1992. Tellus 49B, 409-416.

Bekki, S., Law, K.S., Pyle, J.A., 1994. Effects of ozone depletion on atmospheric $\mathrm{CH}_{4}$ and $\mathrm{CO}$ concentrations. Nature 371, 595-599.

Bellisario, L.M., Bubier, J.L., Moore, T.R., Chanton, J.P., 1999. Controls on $\mathrm{CH}_{4}$ emissions from a northern peatland. Global Biogeochem. Cycles 13, 81-91.

Bender, M., Sowers, T., Brook, E., 1997. Gases in ice cores. Proc. Natl. Acad. Sci. 94, 8343-8349.

Blake, D.R., Rowland, F.S., 1988. Continuing worldwide increase in tropospheric methane, 1978 to 1987 . Science 239, 1129-1131.

Blunier, T., Chappellaz, J., Schwander, J., Barnola, J., Desperts, T., Stauffer, B., Raynaud, D., 1993. Atmospheric methane, record from a Greenland ice core over the last 1000 years. Geophys. Res. Lett. 20, 2219-2222.

Blunier, T., Chapellaz, J., Schwander, J., Stauffer, B., Raynaud, D., 1995. Variations in atmospheric methane concentration during the Holocene Epoch. Nature 374, 46-49.

Blunier, T., Chappellaz, J., Schwander, J., Dällenbach, A., Stauffer, B., Stocker, T.F., Raynaud, D., Jouzel, J., Clausen, H.B., Hammer, C.U., Johnsen, S.J., 1998. Asynchrony of Antarctic and Greenland climate change during the last glacial period. Nature 394, 739-743.

Boeckx, P., VanCleemput, O., Villaralvo, I., 1997. Methane oxidation in soils with different textures and land use. Nutr. Cycling Agroecosyst. 49, 91-95.

Bogner, J., Spokas, K., 1993. Landfill $\mathrm{CH}_{4}$ : rates, fates and role in global carbon cycle. Chemosphere 26, 369-386.

Bogner, J., Spokas, K., Burton, E., Sweeney, R., Corona, V., 1995. Landfills as atmospheric methane sources and sinks. Chemosphere 31, 4119-4130.

Boone, D., 2000. Biological formation and consumption of methane. In: Khalil, M. (Ed.), Atmospheric Methane: Its Role in the Global Environment. Springer-Verlag, New York, NY, pp. 42-62.

Borjesson, G., Svensson, B., 1997. Effects of a gas extraction interruption on emissions of methane and carbon dioxide from a landfill, and on methane oxidation in the cover soil. J. Environ. Qual. 26, 1182-1190.

Brasseur, G., Hitchman, M.H., 1988. Stratospheric response to trace gas perturbations: changes in ozone and temperature distribution. Science 240, 634-637.

Brasseur, G., Kiehl, J., Muller, J.-F., Schneider, T., Granier, C., Tie, X., Hauglustaine, D., 1998. Past and future changes in global tropospheric ozone: impact on radiative forcing. Geophys. Res. Lett. 25, 3807-3810.

Brenninkmeijer, C.A.M., Lowe, D.C., Manning, M.R., Sparks, R.J., van Velthoven, P.F.J., 1995. The ${ }^{13} \mathrm{C},{ }^{14} \mathrm{C}$, and ${ }^{18} \mathrm{O}$ isotopic composition of $\mathrm{CO}, \mathrm{CH}_{4}$, and $\mathrm{CO}_{2}$ in the higher southern latitudes lower stratosphere. J. Geophys. Res. 100, 26163-26172.

Brook, E., Sowers, T., Orchardo, J., 1996. Rapid variations in atmospheric methane concentration during the past 110,000 years. Science 273, 1087-1091.

Brook, E., Harder, S., Severinghaus, J., Steig, E., Sucher, C., 2000. On the origin and timing of rapid changes in atmospheric methane during the last glacial period. Global Biogeochem. Cycles $14,559-572$.
Brown, M., 1995. The singular value decomposition method applied to the deduction of emissions and the isotope composition of atmospheric methane. J. Geophys. Res. 100, 11425-11446.

Bruhl, C., 1993. The impact of the future scenarios for methane and other chemically active gases on the GWP of methane. Chemosphere 26, 731-738.

Brune, W., 1992. Stalking the elusive atmospheric hydroxyl radical. Science 256, 1154-1155.

Buendia, L., Neue, H., Wassmann, R., Lantin, R., Javellana, A., 1997. Understanding the nature of methane emission from rice ecosystems as basis of mitigation strategies. Appl. Energy 56, $433-444$.

Burnett, E.B., Burnett, C.R., 1995. Enhanced production of stratospheric $\mathrm{OH}$ from methane oxidation at elevated reactive chlorine levels in northern midlatitudes. J. Atmos. Chem. 21, 13-41.

Butterbachbahl, K., Papen, H., Rennenberg, H., 1997. Impact of gas transport through rice cultivars on methane emission from rice paddy fields. Plant Cell Environ. 20, 1175-1183.

Cantrell, C.A., Shetter, R.E., McDaniel, A.H., Calvert, J.G., Davidson, J.A., Lowe, D.C., Tyler, S.C., Cicerone, R.J., Greenberg, J.P., 1990. Carbon kinetic isotope effect in the oxidation of methane by hydroxyl radicals. J. Geophys. Res. 95, 2245522462.

Cao, M., Dent, J., Heal, O., 1995. Modeling methane emissions from rice paddies. Global Biogeochem. Cycles 9, 183-195.

Cao, M., Gregson, K., Marshall, S., Dent, J., Heal, O., 1996a. Global methane emissions from rice paddies. Chemosphere 33, 879897.

Cao, M., Marshall, S., Gregson, K., 1996b. Global carbon exchange and methane emissions from natural wetlands: application of a process-based model. J. Geophys. Res. 101, 14399-14414.

Chappellaz, J., Barnola, J., Raynaud, D., Korotkevich, Y., Lorius, C., 1990. Ice-core record of atmospheric methane over the past 160,000 years. Nature $345,127-131$.

Chappellaz, J., Blunier, T., Raynaud, D., Barnola, J., Schwander, J., Stauffer, B., 1993a. Synchronous changes in atmospheric $\mathrm{CH}_{4}$ and Greenland climate between 40-kyr and 8-kyr BP. Nature $366,443-445$.

Chappellaz, J., Fung, I.Y., Thompson, A.M., 1993b. The atmospheric $\mathrm{CH}_{4}$ increase since the Last Glacial Maximum. Tellus $45 \mathrm{~B}$, $228-241$.

Chappellaz, J., Blunier, T., Kints, S., Dallenbach, A., Barnola, J., Schwander, J., Raynaud, D., Stauffer, B., 1997. Changes in the atmospheric $\mathrm{CH}_{4}$ gradient between Greenland and Antarctica during the Holocene. J. Geophys. Res. 102, 15987-15997.

Cicerone, R.J., Oremland, R.S., 1988. Biogeochemical aspects of atmospheric methane. Global Biogeochem. Cycles 2, 299-327.

Cole, C., Duxbury, J., Freney, J., Heinemeyer, O., Minami, K., Mosier, A., Paustian, K., Rosenberg, N., Sampson, N., Sauerbeck, D., Zhao, Q., 1997. Global estimates of potential mitigation of greenhouse gas emissions by agriculture. Nutr. Cycling Agroecosyst. 49, 221-228.

Conny, J.M., Currie, L.A., 1996. The isotopic characterization of methane, non-methane hydrocarbons and formaldehyde in the troposphere. Atmos. Environ. 30, 621-638.

Craig, H., Chou, C.C., 1982. Methane: the record in polar ice cores. Geophys. Res. Lett. 9, 1221-1224. 
Craig, H., Chou, C.C., Welhan, J.A., Stevens, C.M., Engelkemeir, A., 1988. The isotopic composition of methane in polar ice cores. Science 242, 1535-1539.

Crowley, J.N., Saueressig, G., Bergamaschi, P., Fischer, H., Harris, G.W., 1999. Carbon kinetic isotope effect in the reaction $\mathrm{CH}_{4}+\mathrm{Cl}$ : a relative rate study using FTIR spectroscopy. Chem. Phys. Lett. 303, 268-274.

Crutzen, P., 1988. Tropospheric ozone: an overview. In: Isaksen, I.S.A. (Ed.), Tropospheric Ozone: Regional and Global Scale Interactions. Reidel Publishing, Boston, MA, pp. 3-11.

Crutzen, P., 1995. Overview of tropospheric chemistry: developments during the past quarter century and a look ahead. Faraday Discuss. 100, 1-21.

Crutzen, P.J., Andreae, M.O., 1990. Biomass burning in the tropics - Impact on atmospheric chemistry and biogeochemical cycles. Science 250, 1669-1678.

Crutzen, P., Bruhl, C., 1993. A model study of the atmospheric temperatures and concentrations of ozone, hydroxyl, and some other photochemically active gases during the glacial, the preindustrial Holocene and the present. Geophys. Res. Lett. 20, $1047-1050$.

Crutzen, P., Zimmermann, P., 1991. The changing photochemistry of the troposphere. Tellus 43AB, 136-151.

Crutzen, P., Aselmann, I., Seiler, W., 1986. Methane production by domestic animals, wild ruminants, and other herbivorous fauna and humans. Tellus 38B, 271.

Czepiel, P., Mosher, B., Crill, P., Harriss, R., 1996. Quantifying the effect of oxidation on landfill methane emissions. J. Geophys. Res. 101, 16721-16729.

Dällenbach, A., Blunier, T., Flückiger, J., Stauffer, B., Chappellaz, J., Raynaud, D., 2000. Changes in the atmospheric $\mathrm{CH}_{4}$ gradient between Greenland and Antarctica during the Last Glacial and the transition to the Holocene. Geophys. Res. Lett. 27, 10051008 .

Denier van der Gon, H., Neue, H.U., 1995. Influence of organic matter incorporation on the methane emission from a wetland rice field. Global Biogeochem. Cycles 9, 11-22.

Dibb, J., Rasmussen, R., Mayewski, P., Holdsworth, G., 1993. Northern hemisphere concentrations of methane and nitrous oxide since 1800: results from the Mt. Logan and 20D ice cores. Chemosphere 27, 2413-2423.

Dickens, G., Castillo, M., Walker, J., 1997. A blast of gas in the latest Paleocene: simulating first-order effects of massive dissociation of oceanic methane hydrate. Geology 25, 259-262.

Dickinson, R.E., Cicerone, R.J., 1986. Future global warming from atmospheric trace gases. Nature 319, 109-115.

Dlugokencky, E., Steele, L., Lang, P., Masarie, K., 1994a. The growth rate and distribution of atmospheric methane. J. Geophys. Res. 99, 17021-17043.

Dlugokencky, E., Masaire, K., Lang, P., Tans, P., Steele, L., Nisbet, E., 1994b. A dramatic decrease in the growth rate of atmospheric methane in the northern hemisphere during 1992. Geophys. Res. Lett. 21, 45-48.

Dlugokencky, E., Steele, L.P., Lang, P., Masarie, K., 1995. Atmospheric methane at Mauna Loa and Barrow observatories: presentation and analysis of in situ measurements. J. Geophys. Res. $100,23103-23113$.
Dlugokencky, E., Dutton, E., Novelli, P., Tans, P., Masarie, K. Lantz, K., Madronich, S., 1996. Changes in $\mathrm{CH}_{4}$ and $\mathrm{CO}$ growth rates after the eruption of Mt. Pinatubo and their link with changes in tropical tropospheric UV flux. Geophys. Res. Lett. 23, 2761-2764.

Dlugokencky, E., Masarie, K., Tans, P., Conway, T., Xiong, X., 1997. Is the amplitude of the methane seasonal cycle changing? Atmos. Environ. 31, 21-26.

Dlugokencky, E., Masarie, K., Lang, P., Tans, P., 1998. Continuing decline in the growth rate of the atmospheric methane burden. Nature 393, 447-450.

Dobbie, K., Smith, K., 1996. Comparison of $\mathrm{CH}_{4}$ oxidation rates in woodland, arable and set aside soils. Soil Biol. Biochem. 28, $1357-1365$.

Donner, L., Ramanathan, V., 1980. Methane and nitrous oxide: their effects on the terrestrial climate. J. Atmos. Sci. 37, 119124.

Ehhalt, D.H., 1986. On the consequences of a tropospheric $\mathrm{CH}_{4}$ increase to the exospheric density. J. Geophys. Res. 91, 2843.

Environmental Protection Agency, 1993a. In: Hogan, K. (Ed.), Opportunities to Reduce Anthropogenic Methane Emissions in the United States. U.S. EPA, Office of Air and Radiation, EPA 430R-93-012, 420 pp.

Environmental Protection Agency, 1993b. In: Hogan, K. (Ed.), Options for Reducing Methane Emissions Internationally. U.S. EPA, Office of Air and Radiation, EPA 430-R-93-006B, 350 pp.

Etheridge, D., Pearman, G., Fraser, P., 1992. Changes in tropospheric methane between 1841 and 1978 from a high accumulationrate Antarctic ice core. Tellus 44B, 282-294.

Etheridge, D., Steele, L., Francey, R., Langenfelds, R., 1998. Atmospheric methane between 1000 A.D. and present: evidence of anthropogenic emissions and climatic variability. J. Geophys. Res. 103, 15979-15993.

Fishman, J., 1985. Ozone in the troposphere. In: Whitten, R.C., Prasad, S.S. (Eds.), Ozone in the Free Atmosphere. Van Nostrand-Reinhold, New York, NY, pp. 161-194.

Fishman, J., Solomon, S., Crutzen, P.J., 1979. Observational and theoretical evidence in support of a significant in-situ photochemical source of tropospheric ozone. Tellus 31, 432-446.

Francey, R., Manning, M., Allison, C., Coram, S., Etheridge, D., Langenfelds, R., Lowe, D., Steele, L., 1999. A history of $\delta^{13} \mathrm{C}$ in atmospheric $\mathrm{CH}_{4}$ from the Cape Grim Air Archive and Antarctic firn air. J. Geophys. Res. 104, 23631-43643.

Fuglestvedt, J., Jonson, J., Isaksen, I., 1994. Effects of reductions in stratospheric ozone on tropospheric chemistry through changes in photolysis rates. Tellus 46B, 172-192.

Fuglestvedt, J.S., Isaksen, I.S.A., Wang, W.-C., 1996. Estimates of indirect global warming potentials for $\mathrm{CH}_{4}, \mathrm{CO}$ and $\mathrm{NO}_{x}$. Clim. Change 34, 405-437.

Fuglestvedt, J.S., Bernsten, T.K., Isaksen, I.S.A., Mao, H., Liang, X.-Z., Wang, W.-C., 2000. Climatic forcing of nitrogen oxides through changes in tropospheric ozone and methane; global 3D model studies. Atmos. Environ. 33, 961-977.

Fung, I., John, J., Lerner, J., Matthews, E., Prather, M., Steele, L., Fraser, P., 1991. Three-dimensional model synthesis of the global methane cycle. J. Geophys. Res. 96, 13033-13065.

Gas Research Institute (GRI), 1997. Effect of Methane Emissions 
on Global Warming, Appendix B. Gas Research Institute, Chicago, IL.

Gettelman, A., Holton, J.R., Rosenlof, K.H., 1997. Mass fluxes of $\mathrm{O}_{3}, \mathrm{CH}_{4}, \mathrm{~N}_{2} \mathrm{O}$ and $\mathrm{CF}_{2} \mathrm{Cl}_{2}$ in the lower atmosphere calculated from observational data. J. Geophys. Res. 102, 19149-19159.

Gupta, M., Tyler, S., Cicerone, R., 1996. Modeling atmospheric $\delta^{13} \mathrm{CH}_{4}$ and the causes of recent changes in atmospheric $\mathrm{CH}_{4}$ amounts. J. Geophys. Res. 101, 22923-22932.

Hameed, S., Cess, R.D., 1983. Impact of a global warming on biospheric sources of methane and its climatic consequences. Tellus 35B, $1-7$.

Hansen, A.R., Robinson, G.D., 1989. Water vapor and methane in the upper stratosphere: an examination of some of the Nimbus 7 measurements. J. Geophys. Res. 94, 8474-8484.

Hansen, J., Fung, I., Lacis, A., Rind, D., Lebedeff, S., Ruedy, R., Russell, G., Stone, P., 1988. Global climate changes as forecast by Goddard Institute for Space studies three-dimensional model. J. Geophys. Res. 93, 9341-9364.

Hansen, J., Lacis, A., Prather, M., 1989. Greenhouse effect of chlorofluorocarbons and other trace gases. J. Geophys. Res. 94, $16417-16421$.

Hao, W.M., Ward, D.E., 1993. Methane production from global biomass burning. J. Geophys. Res. 98, 20657-20661.

Harper, L.A., Denmead, O.T., Freney, J.R., Byers, F.M., 1999. Direct measurements of methane emissions from grazing and feedlot cattle. J. Anim. Sci. 77, 1392-1401.

Harvey, L.D.D., Huang, Z., 1995. Evaluation of the potential impact of methane clathrate destabilization on future global warming. J. Geophys. Res. 100, 2905-2926.

Hauglustaine, D., Granier, C., Brasseur, G., Megie, G., 1994. The importance of atmospheric chemistry in the calculation of radiative forcing on the climate system. J. Geophys. Res. 99, $1173-$ 1186.

Hayhoe, K., 1997. A modelling study of the role of methane in global climate change. MS Thesis, University of Illinois, Urbana, IL, 146 pp.

Hayhoe, K., Jain, A., Pitcher, H., MacCracken, C., Gibbs, M., Wuebbles, D., Harvey, R., Kruger, D., 1999. Costs of multigreenhouse gas reduction targets for the U.S. Science 286, $905-$ 906.

Hayhoe, K., Jain, A., Kheshgi, H., Wuebbles, D., 2000. Contribution of $\mathrm{CH}_{4}$ to multi-gas reduction targets: the impact of atmospheric chemistry on GWPs. In: van Ham, J. (Ed.), Non- $\mathrm{CO}_{2}$ Greenhouse Gases: Scientific Understanding, Control and Implementation. Kluwer Academic Publishing, Dordrecht, pp. 425-432.

Hein, R., Crutzen, P.J., Heinman, R., 1997. An inverse modeling approach to investigate the global atmospheric methane cycle. Global Biogeochem. Cycles 11, 43-76.

Hilbert, D.W., Roulet, N., Moore, T., 2000. Modelling and analysis of peatlands as dynamical systems. J. Ecol. 88, 230-242.

Hofzumahaus, A., Dorn, H.P., Callies, J., Platt, U., Ehhalt, D., 1991. Tropospheric $\mathrm{OH}$ concentration measurements by laser long-path absorption spectroscopy. Atmos. Environ. 25A, 2017-2022.

Hogan, K., Harriss, R.C., 1994. Comments on "A dramatic decrease in the growth rate of atmospheric methane in the northern hemisphere during 1992" by E.J. Dlugokencky et al. Geophys. Res. Lett. 21, 2445-2447.
Holmes, M.E., Sansone, F.J., Rust, T.M., Popp, B.N., 2000. Methane production, consumption, and air-sea exchange in the open ocean: an evaluation based on carbon isotopic ratios. Global Biogeochem. Cycles 14, 1-10.

Hough, A.M., Derwent, R.G., 1990. Changes in the global concentration of tropospheric ozone due to human activities. Nature 344, 645-648.

Houweling, S., Kaminski, T., Dentener, F., Lelieveld, J., Heimann, M., 1999. Inverse modeling of methane sources and sinks using the adjoint of a global transport model. J. Geophys. Res. 104, 26137-26160.

Huang, Y., Sass, R.L., Fisher, F.M., 1997. Methane emission from Texas rice paddy soils: 1 . Quantitative multi-year dependence of $\mathrm{CH}_{4}$ emission on soil, cultivar and grain yield. Global Change Biol. 3, 479-489.

Huang, Y., Sass, R.L., Fisher, F.M., 1998. A semi-empirical model of methane emission from flooded rice paddy soils. Global Change Biol. 4, 247-268.

Hudgens, D., Yavitt, J., 1997. Land-use effects on soil methane and carbon dioxide fluxes in forests near Ithaca, New York. Ecoscience 4, 214-222.

Intergovernmental Panel on Climate Change, 1990. In: Houghton, J.T., Jenkins, G.J., Ephraums, J.J. (Eds.), Climate Change: The IPCC Scientific Assessment. Cambridge Univ. Press, Cambridge, UK.

Intergovernmental Panel on Climate Change, 1995. In: Houghton, J.T., Meira Filho, L., Bruce, J., Lee, H., Callander, B., Haites, E., Harris, H., Maskell, K. (Eds.), Climate Change 1994. Cambridge Univ. Press, Cambridge, UK, 339 pp.

Intergovernmental Panel on Climate Change, 1996. In: Houghton, J.T., Meira Filho, L.G., Callander, B.A., Harris, N., Kattenberg, A., Maskell, K. (Eds.), Climate Change 1995: The Science of Climate Change. Cambridge Univ. Press, Cambridge, UK, 572 pp.

Isaksen, I.S.A., 1988. Is the oxidizing capacity of the atmosphere changing? In: Rowland, F.S., Isaksen, I.S.A. (Eds.), The Changing Atmosphere. Wiley, New York, NY, pp. 141-157.

Isaksen, I.S.A., Stordal, F., 1986. Ozone perturbations by enhanced levels of CFCs, $\mathrm{N}_{2} \mathrm{O}$, and $\mathrm{CH}_{4}$ : a two-dimensional diabatic circulation study including uncertainty estimates. J. Geophys. Res. 91, 5249-5263.

Jain, A.K., Briegleb, B.P., Minschwaner, K., Wuebbles, D.J., 2000. Radiative forcings and global warming potentials of 39 greenhouse gases. J. Geophys. Res. 105, 20773-20790.

Joabsson, A., Christensen, T.R., Wallen, B., 1999. Vascular plant controls on methane emissions from northern peatforming wetlands. Trends Ecol. Evol. 14, 385-388.

Johnson, D., Johnson, K., Ward, G.M., Branine, M., 2000. Ruminants and other animals. In: Khalil, M. (Ed.), Atmospheric Methane: Its Role in the Global Environment. Springer-Verlag, New York, NY, pp. 112-133.

Jouzel, J., Jouzel, N.I., Barkov, J.M., Barnola, M., Bender, J., Chappellaz, C., Genthon, V.M., Kotlyakov, V., Lipenkov, C., Lorius, J.R., Petit, D., Raynaud, G., Raisbeck, C., Ritz, T., Sowers, M., Stievenard, F., Yiou, F., Yiou, P., 1993. Extending the Vostok ice-core record of palaeoclimate to the penultimate glacial period. Nature 364, 407-412. 
Judd, A.G., 2000. Geological sources of methane. In: Khalil, M. (Ed.), Atmospheric Methane: Its Role in the Global Environment. Springer-Verlag, New York, NY, pp. 280-303.

Kandlikar, M., 1997. Bayesian inversion for reconciling uncertainties in global mass balances. Tellus 49B, 123-135.

Kandlikar, M., McRae, G.J., 1995. Inversion of the global methane cycle using change constrained programming: methodology and results. Chemosphere 30, 1151-1170.

Karlsdottir, S., Isaksen, I.S.A., 2000. Changing methane lifetime: possible cause for reduced growth. Geophys. Res. Lett. 27, $93-$ 96.

Khalil, M.A.K., 2000. Atmospheric methane: an introduction. In: Khalil, M. (Ed.), Atmospheric Methane: Its Role in the Global Environment. Springer-Verlag, New York, NY, pp. 1-8.

Khalil, M.A.K., Rasmussen, R.A., 1983. Sources, sinks and seasonal cycles of atmospheric methane. J. Geophys. Res. 88, 51315144.

Khalil, M.A.K., Rasmussen, R.A., 1985. Causes of increasing atmospheric methane: depletion of hydroxyl radicals and the rise of emissions. Atmos. Environ. 13, 397-407.

Khalil, M., Rasmussen, R., 1987. Atmospheric methane: trends over the last 10,000 years. Atmos. Environ. 21, 2445-2452.

Khalil, M., Rasmussen, R., 1993. Decreasing trend of methane: unpredictability of future concentrations. Chemosphere 26, $803-$ 814.

Khalil, M., Rasmussen, R., 1994a. Global emissions of methane during the last several centuries. Chemosphere 29, 833-842.

Khalil, M., Rasmussen, R., 1994b. Trends in atmospheric methane. Pure and Applied Chemistry. 66, Special Report: Methane in the Atmosphere, Commission on Atmospheric Chemistry.

Khalil, M., Shearer, M.J., 2000. Sources of methane: an overview. In: Khalil, M. (Ed.), Atmospheric Methane: Its Role in the Global Environment. Springer-Verlag, New York, NY, pp. 98-111.

Khalil, M., Rasmussen, R., Moraes, F., 1993a. Atmospheric methane at Cape Meares: analysis of a high-resolution data base and its environmental implications. J. Geophys. Res. 98, 14753-14770.

Khalil, M., Rasmussen, R., Shearer, M., Ge, S., Rau, J., 1993 b. Methane from coal burning. Chemosphere 26, 473-477.

Khalil, M., Rasmussen, R., Shearer, M., Dalluge, R., Ren, L., Duan, C., 1998. Factors affecting methane emissions from rice fields. J. Geophys. Res. 103, 25219-25231.

Kheshgi, H.S., Jain, A.K., Kotamarthi, V.R., Wuebbles, D.J., 1999. Future atmospheric methane concentrations in the context of the stabilization of greenhouse gas concentrations. J. Geophys. Res. 104, 19183-19190.

King, G., 1997. Responses of atmospheric methane consumption by soils to global climate change. Global Change Biol. 3, 351362.

King, S.L., Quay, P.D., Lansdown, J.M., 1989. The ${ }^{13} \mathrm{C} /{ }^{12} \mathrm{C}$ kinetic isotope effect for soil oxidation of methane at ambient atmospheric concentrations. J. Geophys. Res. 94, 18273-18277.

King, J.Y., Reeburgh, W.S., Regli, S.K., 1998. Methane emission and transport by arctic sedges in Alaska: results of a vegetation removal experiment. J. Geophys. Res. 103, 29029-29083.

Kirchgessner, D.A., 2000. Fossil fuel industries. In: Khalil, M. (Ed.), Atmospheric Methane: Its Role in the Global Environment. Springer-Verlag, New York, NY, pp. 263-279.
Kirchgessner, D.A., Piccot, S.D., Winkler, J.D., 1993. Estimate of global methane emissions from coal mines. Chemosphere 26, $453-472$.

Krol, M., van Leeuwen, P., Lelieveld, J., 1998. Global OH trend inferred from methylchloroform measurements. J. Geophys. Res. 103, 10697-10711.

Lacroix, A.V., 1993. Unaccounted-for sources of fossil and isotopically-enriched methane and their contribution to the emissions inventory-A review and synthesis. Chemosphere 26, 507557.

Lashof, D., 1989. The dynamic greenhouse: feedback processes that may influence future concentrations of atmospheric trace gases and climatic change. Clim. Change 14, 213-242.

Lassey, K.R., Lowe, D.C., Brenninkmeijer, C.A.M., Gomez, A.J., 1993. Atmospheric methane and its carbon isotopes in the Southern Hemisphere: their time series and an instructive model. Chemosphere 26, 95-109.

Lassey, K.R., Lowe, D.C., Manning, M.R., 1999. The trend in atmospheric methane $\delta^{13} \mathrm{C}$ and implications for isotopic constraints on the global methane budget. Global Biogeochem. Cycles 14, 41-49.

Law, K.S., Nisbet, E.G., 1996. Sensitivity of the $\mathrm{CH}_{4}$ growth rate to changes in $\mathrm{CH}_{4}$ emissions from natural gas and coal. J. Geophys. Res. 101, 14387-14397.

Legrand, M., Lorius, C., Barkov, N., Petrov, V., 1988. Vostok (Antarctic ice core): atmospheric chemistry changes over the last climatic cycle (160,000 years). Atmos. Environ. 22, 317-331.

Lelieveld, J., Crutzen, P.J., 1991. The role of clouds in tropospheric photochemistry. J. Atmos. Chem. 12, 229-267.

Lelieveld, J., Crutzen, P.J., 1992. Indirect chemical effects of methane on global warming. Nature $355,339-342$.

Lelieveld, J., Crutzen, P., Bruhl, C., 1993. Climate effects of atmospheric methane. Chemosphere 26, 739-767.

Lelieveld, J., Crutzen, P., Dentener, F., 1998. Changing concentration, lifetime and climate forcing of atmospheric methane. Tellus 50B, $128-150$.

Le Texier, L., Solomon, S., Garcia, R.R., 1988. The role of molecular hydrogen and methane oxidation in the water vapor budget of the stratosphere. Q. J. R. Meteorol. Soc. 114, 281-296.

Levine, J.S., Cofer III, W.R., Pinto, J.P., 2000. Biomass burning. In: Khalil, M. (Ed.), Atmospheric Methane: Its Role in the Global Environment. Springer-Verlag, New York, NY, pp. 190-201.

Lowe, D.C., Schmidt, U., 1983. Formaldehyde (HCHO) measurements in the nonurban atmosphere. J. Geophys. Res. 88, 10844 10858.

Lowe, D.C., Brenninkmeijer, C.A.M., Brailsford, G.W., Lassey, K.R., Gomez, A.J., 1994. Concentration and ${ }^{13} \mathrm{C}$ records of atmospheric methane in New Zealand and Antarctica: evidence for changes in methane sources. J. Geophys. Res. 99, $16913-$ 16925.

Lowe, D., Manning, M., Brailsford, G., Bromley, A., 1997. The 1991-1992 atmospheric methane anomaly: Southern Hemisphere ${ }^{13} \mathrm{C}$ increase and growth rate fluctuations. Geophys. Res. Lett. 24, 857-860.

Lowe, D.C., Allen, W., Manning, M.R., Bromley, T., Brailsford, G., Ferretti, D., Gomez, A., Knobben, R., Martin, R., Mei, Z., Moss, R., Koshy, K., Maata, M., 1999. Shipboard determinations of 
the distribution of $\delta^{13} \mathrm{C}$ in atmospheric methane in the Pacific. J. Geophys. Res. 104, 23135-26125.

Lu, Y., Khalil, M., 1991. Tropospheric OH: model calculations of spatial, temporal, and secular variations. Chemosphere 23, 397-444.

MacDonald, G.J., 1990. Role of methane clathrates in past and future climates. Clim. Change 16, 247-281.

MacKay, R.M., Khalil, M.A.K., 1991. Theory and development of a one dimensional time dependent radiative convective climate model. Chemosphere 22, 383-417.

Mancinelli, R., 1995. The regulation of methane oxidation in soil. Annu. Rev. Microbiol. 49, 581-605.

Manning, M.R., Lowe, D.C., Melhuish, W.H., Sparks, R.J., Wallace, G., Brenninkmeijer, C.A.M., McGill, R.C., 1990. The use of radiocarbon measurements in atmospheric studies. Radiocarbon $32,37-58$.

Matthews, E., 1994. Assessment of methane sources and their uncertainties. Pure Appl. Chem. 66, 154-161.

Matthews, E., 2000. Wetlands. In: Khalil, M. (Ed.), Atmospheric Methane: Its Role in the Global Environment. Springer-Verlag, New York, NY, pp. 202-233.

Miller, D.N., Ghiorse, W.C., Yavitt, J.B., 1999. Seasonal patterns and controls on methane and carbon dioxide fluxes in forested swamp pools. Geomicrobiol. J. 16, 325-331.

Minami, K., 1997. Atmospheric methane and nitrous oxide: sources, sinks and strategies for reducing agricultural emissions. Nutr. Cycling Agroecosyst. 49, 203-211.

Minami, K., Neue, H.U., 1994. Rice paddies as a methane source. Clim. Change 27, 13-26.

Minschwaner, K., Carver, R.W., Briegleb, B.P., Roche, A.E., 1998. Infrared radiative forcing and atmospheric lifetimes of trace species based on observations from UARS. J. Geophys. Res. $103,23243-23253$.

Mitchell, C., 1993. Methane emissions from the coal and natural gas industries in the UK. Chemosphere 26, 441-446.

Mitra, S., Jain, M., Kumar, S., Bandyopadhyay, S., Kalra, N., 1999. Effect of rice cultivars on methane emission. Agricult., Ecosyst. Environ. 73, 177-183.

Moosavi, S.C., Crill, P.M., 1997. Controls on $\mathrm{CH}_{4}$ and $\mathrm{CO}_{2}$ emissions along two moisture gradients in the Canadian boreal zone. J. Geophys. Res. 102, 29261-29277.

Moosavi, S.C., Crill, P.M., 1998. $\mathrm{CH}_{4}$ oxidation by tundra wetlands as measured by a selective inhibitor technique. J. Geophys. Res. 103, 29093-29106.

Moosavi, S.C., Crill, P.M., Pullman, E.R., Funk, D.W., Peterson, K.M., 1996. Controls on $\mathrm{CH}_{4}$ flux from an Alaskan boreal wetland. Global Biogeochem. Cycles 10, 287-296.

Mosier, A., Delgado, J., Cochran, V., Valentine, D., Parton, W., 1997a. Impact of agriculture on soil consumption of atmospheric $\mathrm{CH}_{4}$ and a comparison of $\mathrm{CH}_{4}$ and $\mathrm{N}_{2} \mathrm{O}$ flux in subarctic, temperature and tropical grasslands. Nutr. Cycling Agroecosyst. 49, $71-83$.

Mosier, A., Parton, W., Valentine, D., Ojima, D., Schimel, D., Heinemeyer, O., 1997b. $\mathrm{CH}_{4}$ and $\mathrm{N}_{2} \mathrm{O}$ fluxes in the Colorado shortgrass steppe: 2. Long-term impact of land use change. Global Biogeochem. Cycle 11, 29-42.

Nakano, T., Kuniyoshi, S., Fukuda, M., 2000. Temporal variation in methane emission from tundra wetlands in a permafrost area, northeastern Siberia. Atmos. Environ. 34, 1205-1213.

Nakazawa, T., Machida, T., Tanaka, M., Fujii, Y., Aoki, S., Watanabe, O., 1993. Differences of the atmospheric $\mathrm{CH}_{4}$ concentration between the Arctic and Antarctic regions in preindustrial/pre-agricultural era. Geophys. Res. Lett. 20, $943-$ 946.

Neue, H.-U., Roger, P.A., 2000. Rice agriculture: factors controlling emissions. In: Khalil, M. (Ed.), Atmospheric Methane: Its Role in the Global Environment. Springer-Verlag, New York, NY, pp. $134-169$.

Neue, H.-U., Wassmann, R., Kludze, H., Bujun, W., Lantin, R., 1997. Factors and processes controlling methane emissions from rice fields. Nutr. Cycling Agroecosyst. 49, 111-117.

Nisbet, E., 1990a. Did the release of methane from hydrates accelerate the end of the last ice age? Can. J. of Earth Science 27, $148-157$.

Nisbet, E., 1990b. Climate change and methane. Nature 347, 23.

Oberbauer, S., Starr, G., Pop, E., 1998. Effects of extended growing season and soil warming on carbon dioxide and methane exchange of tussock tundra in Alaska. J. Geophys. Res. 103, 29075-29082.

Osborn, T., Wigley, T., 1994. A simple model for estimating methane concentration and lifetime variations. Clim. Dyn. 9, 181-193.

Otter, L.B., Scholes, M.C., 2000. Methane sources and sinks in a periodically flooded South African savanna. Global Biogeochem. Cycles 14, 97-111.

Owens, A.J., Steed, J.M., Filkin, D.L., Miller, C., Jesson, J.P., 1982. The potential effects of increased methane on atmospheric ozone. Geophys. Res. Lett. 9, 1105-1108.

Owens, A.J., Hales, C.H., Filkin, D.L., Miller, C., Steed, J.M., Jesson, J.P., 1985. A coupled one-dimensional radiative-convective, chemistry-transport model of the atmosphere: 1 . Model structure and steady state perturbation calculations. J. Geophys. Res. 90, 2283-2311.

Panikov, N.S., 1999. Fluxes of $\mathrm{CO}_{2}$ and $\mathrm{CH}_{4}$ in high latitude wetlands: measuring, modelling and predicting response to climate change. Polar Res. 18, 237-244.

Peer, R., Thorneloe, S., Epperson, D., 1993. A comparison of methods for estimating global methane emissions from landfills. Chemosphere 26, 387-400.

Penkett, S.A., 1988. Indications and causes of ozone increase in the troposphere. In: Rowland, F.S., Isaksen, I.S.A. (Eds.), The Changing Atmosphere. Wiley, New York, NY, pp. 91-103.

Petit, J., Jouzel, J., Raynaud, D., Barkov, N., Barnola, J.-M., Basile, I., Bender, M., Chappellaz, J., Davis, M., Delaygue, G., Delmotte, M., Kotlyakov, V., Legrand, M., Lipenkov, V., Lorius, C., Pepin, L., Ritz, C., Saltzman, E., Stievenard, M., 1999. Climate and atmospheric history of the past 420,000 years from the Vostok ice core, Antarctica. Nature 399, 429-436.

Piccot, S.D., Beck, L., Srinivasan, S., Kersteter, S.L., 1996. Global methane emissions from minor anthropogenic sources and biofuel combustion in residential stoves. J. Geophys. Res. 101, 22757-22766.

Pinto, J., Khalil, M., 1991. The stability of tropospheric OH during ice ages, inter-glacial epochs and modern times. Tellus 43B, $347-352$. 
Poppe, D., Zimmerman, J., Dorn, H., 1995. Field data and model calculations for the hydroxyl radical. J. Atmos. Sci. 52, 34023407.

Powlson, D., Goulding, K., Willison, T., Webster, C., Hutsch, B., 1997. The effect of agriculture on methane oxidation in soil. Nutr. Cycling Agroecosyst. 49, 59-70.

Prather, M., 1994. Lifetimes and eigenstates in atmospheric chemistry. Geophys. Res. Lett. 21, 801-804.

Prieme, A., Christensen, S., Dobbie, K., Smith, K., 1997. Slow increase in rate of methane oxidation in soils with time following land use change from arable agriculture to woodland. Soil Biol. Biochem. 29, 1269-1273.

Prinn, R.G., Weiss, R.F., Miller, B.R., Huang, J., Alyea, F.N., Cunnold, D.M., Fraser, P.J., Hartley, D.E., Simmonds, P.G., 1995. Atmospheric trends and lifetime of $\mathrm{CH}_{3} \mathrm{CCl}_{3}$ and global $\mathrm{OH}$ concentrations. Science 269, 187-198.

Quay, P.D., King, S.L., Lansdown, J.M., Wilbur, D.O., 1988. Isotopic composition of methane released from wetlands: implications for the increase in atmospheric methane. Global Biogeochem. Cycles 2, 385-397.

Quay, P.D., King, S.L., Stutsman, J., Wilbur, D.O., Steele, L.P., Fung, I., Gammon, R.H., Brown, T.A., Farwell, G.W., Grootes, P.M., Schmidt, F.H., 1991. Carbon isotopic composition of atmospheric $\mathrm{CH}_{4}$ : fossil and biomass burning source strengths. Global Biogeochem. Cycles 5, 25-47.

Quay, P., Stutsman, J., Wilbur, D., Snover, A., Dlugokencky, E., Brown, T., 1999. The isotopic composition of atmospheric methane. Global Biogeochem. Cycles 13, 445-461.

Rahmes, T.F., Omar, A.H., Wuebbles, D.J., 1998. Atmospheric distributions of soot particles by current and future aircraft fleets and resulting radiative forcing on climate. J. Geophys. Res. 103, $31657-31667$.

Ramanathan, V., 1988. The radiative and climatic consequences of the changing atmospheric composition of trace gases. In: Rowland, F.S., Isaksen, I.S.A. (Eds.), The Changing Atmosphere. Wiley, New York, NY, pp. 159-186.

Ramanathan, V., Cicerone, R.J., Singh, H.B., Kiehl, J.T., 1985. Trace gas trends and their potential role in climate change. J. Geophys. Res. 90, 5547-5566.

Ramanathan, V., Callis, L., Cess, R., Hansen, J., Isaksen, I., Kuhn, W., Lacis, A., Luther, F., Mahlman, J., Reck, R., Schlesinger, M., 1987. Climate-chemical interactions and effects of changing atmospheric trace gases. Rev. Geophys. 25, 1441-1482.

Randel, W.J., Wu, F., Russell III, J.M., Roche, A., Waters, J.W., 1998. Seasonal cycles and QBO variations in stratospheric $\mathrm{CH}_{4}$ and $\mathrm{H}_{2} \mathrm{O}$ observed in UARS HALOE data. J. Atmos. Sci. 55, $163-185$.

Randel, W., Wu, F., Russell III, J., Waters, J. 1999. Space-time patterns of trends in stratospheric constituents derived from UARS measurements. J. Geophys. Res. 104, 3711-3727.

Rasmussen, R.A., Khalil, M.A.K., 1981. Atmospheric methane $\left(\mathrm{CH}_{4}\right)$ : trends and seasonal cycles. J. Geophys. Res. 86, 98269832.

Raynaud, D., Chappellaz, J., Barnola, J., Korotkevich, Y., Lorius, C., 1988. Climatic and $\mathrm{CH} 4$ cycle implications of glacial-interglacial $\mathrm{CH}_{4}$ change in the Vostok ice core. Nature 333, 655-657.

Raynaud, D., Jouzel, J., Barnola, J., Chapellaz, J., Delmas, R.,
Lorius, C., 1993. The ice record of greenhouse gases. Science 259, 926-934.

Rinsland, C., Levine, J., Miles, T., 1985. Concentration of methane in the troposphere deduced from 1951 infrared solar spectra. Nature 318, 245-249.

Roble, R.G., Dickinson, R.E., 1989. How will changes in carbon dioxide and methane modify the mean structure of the mesosphere and thermosphere? Geophys. Res. Lett. 16, 1441-1444.

Rodhe, H., 1990. A comparison of the contribution of various gases to the greenhouse effect. Science 248, 1217-1219.

Roulet, N., Moore, T., Bubier, J., Lafleur, P., 1992. Northern fens: methane flux and climatic change. Tellus 44B, 100-105.

Roulet, N., Jano, A., Kelly, C., Klinger, L., Moore, T., Protz, R., Ritter, J., Rouse, W., 1993. The Hudson Bay Lowland as a source of atmospheric methane. J. Geophys. Res. 99, 1439-1454.

Sanderson, M.G., 1996. Biomass of termites and their emissions of methane and carbon dioxide: a global database. Global Biogeochem. Cycles 10, 543-557.

Sass, R.L., Fisher, F.M., 1997. Methane emissions from rice paddies: a process study summary. Nutr. Cycling Agroecosyst. 49, $119-127$.

Sass, R.L., Fisher, F.M., Ding, A., Huang, Y., 1999. Exchange of methane from rice fields: national, regional, and global budgets. J. Geophys. Res. 104, 26943-26951.

Saueressig, G., Bergamaschi, P., Crowley, J.N., Fischer, H., Harris, G.W., 1995. Carbon kinetic isotope effect in the reaction of $\mathrm{CH}_{4}$ with $\mathrm{Cl}$ atmos. Geophys. Res. Lett. 22, 1225-1228.

Schauffler, S., Daniel, J., 1994. On the effect of stratospheric circulation changes on trace gas trends. J. Geophys. Res. 99, 25747-25754.

Seiler, W., Crutzen, P.J., 1980. Estimates of gross and net fluxes of carbon between the biosphere and the atmosphere from biomass burning. Climatic Change 2, 207-247.

Severinghaus, J., Sowers, T., Brook, E., Aley, R., Bender, M., 1998. Timing of abrupt climate change at the end of the Younger Dryas interval from thermally fractionated gases in polar ice. Nature 391, 141-146.

Shearer, M.J., Khalil, M.A.K., 2000. Rice agriculture: emissions. In: Khalil, M. (Ed.), Atmospheric Methane: Its Role in the Global Environment. Springer-Verlag, New York, NY, pp. 170-189.

Sigren, L., Lewis, S., Fisher, F., Sass, R., 1997. Effects of field drainage on soil parameters related to methane production and emission from rice paddies. Global Biogeochem. Cycles 11, 151-162.

Slanina, J., Warneck, P., Bazhin, N., Akimoto, H., Kieskamp, W., Khalil, M., Calvert, J., Matthews, E., Barrie, L., Wahlen, M., Schwartz, S., Tang, X., Singh, O., 1994. Assessment of uncertainties in the projected concentrations of methane in the atmosphere. Pure Appl. Chem. 66, 137-140.

Smith, L.K., Lewis, W.M., Chanton, J.P., Cronin, G., Hamilton, S.K., 2000. Methane emissions from the Orinoco River floodplain, Venezuela. Biogeochemistry 51, 113-140.

Snover, A.K., Quay, P.D., 2000. Hydrogen and carbon kinetic isotope effects during soil uptake of atmospheric methane. Global Biogeochem. Cycles 14, 25-39.

Steele, L., Dlugokencky, E., Lang, P., Tans, P., Martin, R., Masarie, K., 1992. Slowing down of the global accumulation of atmospheric methane during the 1980s. Nature 358, 313-316. 
Stern, D., Kaufmann, R., 1996. Estimates of global anthropogenic methane emissions 1860-1993. Chemosphere 33, 159-176.

Stevens, C., 1993. Isotopic abundance in the atmosphere and sources. In: Khalil, M.A.K. (Ed.), Atmospheric Methane, Sources, Sinks and Role in Global Change. Springer-Verlag, New York, pp. $62-88$.

Stevens, C.M., Engelkemeir, A., 1988. Stable carbon isotopic composition of methane from some natural and anthropogenic sources. J. Geophys. Res. 93, 725-733.

Stevens, C.M., Rust, F.E., 1982. The carbon isotopic composition of atmospheric methane. J. Geophys. Res. 87, 4879-4882.

Stevens, C.M., Wahlen, M., 2000. The isotopic composition of athmospheric methane and its sources. In: Khalil, M. (Ed.), Atmospheric Methane: Its role in the Global Environment. Springer-Verlag, New York, pp. 25-41.

Stordal, F., Isaksen, I.S.A., 1987. Ozone perturbations due to increases in $\mathrm{N}_{2} \mathrm{O}, \mathrm{CH}_{4}$, and chlorocarbons: two-dimensional timedependent calculations. Tellus 39B, 333-353.

Subak, S., 1994. Methane from the House of Tudor and the Ming Dynasty: anthropogenic emissions in the sixteenth century. Chemosphere 29, 843-854.

Sugimoto, A., Inoue, T., Kirtibutr, N., Abe, T., 1998. Methane oxidation by termite mounds estimated by the carbon isotopic composition of methane. Global Biogeochem. Cycles 12, 595-605.

Tang, X., Madronich, S., Wallington, T., Calamari, D., 1998. Changes in tropospheric composition and air quality. J. Photochem. Photobiol., B 46, 83-95.

Tans, P.P., 1997. A note on isotopic ratios and the global methane budget. Global Biogeochem. Cycles 11, 77-81.

Thomas, G., Olivero, J., Jensen, E., Schroeder, W., Toon, O., 1989. Relation between increasing methane and the presence of ice clouds at the mesopause. Nature 338, 490-492.

Thompson, A., 1992. The oxidizing capacity of the Earth's atmosphere: probable past and future changes. Science 256, $1157-$ 1165.

Thompson, A., Cicerone, R., 1986. Atmospheric $\mathrm{CH}_{4}, \mathrm{CO}$ and $\mathrm{OH}$ from 1860 to 1985 . Nature 321, 148-150.

Thompson, A., Stewart, R., Owens, M., Herwehe, J., 1989. Sensitivity of tropospheric oxidants to global chemical and climate change. Atmos. Environ. 23, 519-532.

Thompson, A., Huntley, M., Stewart, R., 1990. Perturbations to tropospheric oxidants, 1985-2035: calculations of ozone and $\mathrm{OH}$ in chemically coherent regions. J. Geophys. Res. 95, 98299844.

Thompson, A., Chappellaz, J., Fung, I., Kucsera, T., 1993. The atmospheric $\mathrm{CH}_{4}$ increase since the Last Glacial Maximum: 2 . Interactions with oxidants. Tellus 45B, 242-257.

Thorneloe, S.A., Barlaz, M.A., Peer, R., Huff, L.C., Davis, L., Mangino, J., 2000. Waste management. In: Khalil, M. (Ed.), Atmospheric Methane: Its Role in the Global Environment. SpringerVerlag, New York, NY, pp. 234-262.

Thorpe, R., Law, K., Bekki, S., Pyle, J., Nisbet, E., 1996. Is methane-driven deglaciation consistent with the ice core record? J. Geophys. Res. 101, 28627-28635.

Tyler, S.C., 1986. Stable carbon isotope ratios in atmospheric methane and some of its sources. J. Geophys. Res. 91, 1323213238 .
Tyler, S.C., 1989. ${ }^{13} \mathrm{C} /{ }^{12} \mathrm{C}$ ratios in atmospheric methane and some of its sources. Stable Isotopes in Ecological Research. SpringerVerlag, New York, pp. 395-409.

Tyler, S.C., 1999. Measurements and modeling of atmospheric methane using stable carbon isotopes. IGACtivities, pp. 3-7, March.

Tyler, S.C., Blake, D.R., Rowland, F.S., $1987 .{ }^{13} \mathrm{C} /{ }^{12} \mathrm{C}$ ratio in methane from the flooded amazon forest. J. Geophys. Res. 92, 1044-1048.

Tyler, S.C., Crill, P.M., Brailsford, G.W., $1994 .{ }^{13} \mathrm{C} /{ }^{12} \mathrm{C}$ fractionation of methane during oxidation in a temperate forested soil. Geochim. Cosmochim. Acta 58, 1625-1633.

Tyler, S.C., Ajie, H.O., Gupta, M.L., Cicerone, R.J., Blake, D.R., Dlugokencky, E.J., 1999. Stable carbon isotopic composition of atmospheric methane: a comparison of surface level and free tropospheric air. J. Geophys. Res. 104, 13895-13910.

Tyler, S.C., Ajie, H.O., Rice, A.L., Cicerone, R.J., Tuazon, E.C., 2000. Experimentally determined kinetic isotope effects in the reaction of $\mathrm{CH}_{4}$ with $\mathrm{Cl}$ : implications for atmospheric $\mathrm{CH}_{4}$. Geophys. Res. Lett. 27, 1715-1718.

UNFCCC, 1997. Kyoto Protocol to the United Nations Framework Convention on Climate Change. UNFCCC/CP/1997/L.7/Add.1, United Nations.

Van den Pol-Van Dasselaar, A., Van Beusichem, M.L., Oenema, O., 1999. Methane emissions from wet grasslands on peat soil in a nature preserve. Biogeochemistry 44, 205-220.

Van der Nat, F.J., Middelburg, J.J., 2000. Methane emission from tidal freshwater marshes. Biogeochemistry 49, 103-121.

Velichko, A., Kremenetski, C., Borisova, O., Zelikson, E., Nechaev, V., Faure, H., 1998. Estimates of methane emission during the last 125,000 years in Northern Eurasia. Global Planet. Change 16-17, 159-180.

Wahlen, S.C., Reeburgh, W.S., 1992. Interannual variations in tundra methane emission: a 4-year time-series at fixed sites. Global Biogeochem. Cycles 6, 139-159.

Wahlen, M., Tanaka, N., Henry, R., Deck, B., Zeglen, J., Vogel, J.S., Southon, J., Shemesh, A., Fairbanks, R., Broecker, W.S., 1989. Carbon-14 in methane sources and in atmospheric methane: the contribution from fossil carbon. Science 245, 286-290.

Wang, Y., Jacob, D.J., 1998. Anthropogenic forcing on tropospheric ozone and $\mathrm{OH}$ since preindustrial times. J. Geophys. Res. 103, 31123-31135.

Wang, W.C., Molnar, G., 1985. A model study of the greenhouse effects due to increasing atmospheric $\mathrm{CH}_{4}, \mathrm{~N}_{2} \mathrm{O}, \mathrm{CF}_{2} \mathrm{C}_{12}$ and $\mathrm{CFCl}_{3}$. J. Geophys. Res. 90, 12971-12980.

Wang, W.C., Wuebbles, D.J., Washington, W.M., Isaacs, R.G., Molnar, G., 1986. Trace gases and other potential perturbations to global climate. Rev. Geophys. 24, 110-140.

Wang, W.C., Dudek, M.P., Liang, X.Z., Kiehl, J.T., 1991. Inadequacy of effective $\mathrm{CO}_{2}$ as a proxy in simulating the greenhouse effect of other radiatively active gases. Nature 350, 573-577.

Wang, C., Prinn, R., Sokolov, A., 1998. A global interactive chemistry and climate model: formulation and testing. J. Geophys. Res. 103, 3399-3417.

Ward, G., Doxtader, K., Miller, W., Johnson, D., 1993. Effects of intensification of agricultural practices on emission of greenhouse gases. Chemosphere 26, 87-93. 
Whiticar, M.J., 2000. Can stable isotopes and global budgets be used to constrain atmospheric methane budgets? In: Khalil, M. (Ed.), Atmospheric Methane: Its Role in the Global Environment. Springer-Verlag, New York, NY, pp. 63-85.

Wickland, K.P., Striegl, R.G., Schmidt, S.K., Mast, M.A., 1999. Methane flux in subalpine wetland and unsaturated soils in the southern Rocky Mountains. Global Biogeochem. Cycles 13, $101-113$.

Wigley, T.M.L., 1987. Relative contributions of different trace gases to the greenhouse effect. Clim. Monit. 16, 14-28.

World Meteorological Organization, 1985. Scientific Assessment of Ozone Depletion: 1985. Global Ozone and Research and Monitoring Project Report 16, Geneva.

World Meteorological Organization, 1989. Scientific Assessment of Ozone Depletion: 1989. Global Ozone and Research and Monitoring Project Report 20, Geneva.

World Meteorological Organization, 1991. Scientific Assessment of Ozone Depletion: 1991. Global Ozone and Research and Monitoring Project Report 25, Geneva.

World Meteorological Organization, 1995. Scientific Assessment of Ozone Depletion: 1994. Global Ozone and Research And Monitoring Project Report 37, Geneva.

World Meteorological Organization, 1999. Scientific Assessment of Ozone Depletion: 1998. Global Ozone and Research And Monitoring Project Report 44, Geneva.
Worthy, D., Levin, I., Hopper, F., Ernst, M., Trivett, N., 2000 Evidence for a link between climate and northern wetland methane emissions. J. Geophys. Res. 105, 4031-4038.

Wuebbles, D.J., Luther, F.M., Penner, J.E., 1983. Effect of coupled anthropogenic perturbations on stratospheric ozone. J. Geophys. Res. 88, 1444-1456.

Wuebbles, D.J., Wei, C.-F., Patten, K.O., 1998. Effects on stratospheric ozone and temperature during the Maunder Minimum. Geophys. Res. Lett. 25, 523-526.

Wuebbles, D., Hayhoe, K., Kotamarthi, R., 2000. Atmospheric methane in the global environment. In: Khalil, M. (Ed.), Atmospheric Methane: Its Role in the Global Environment. SpringerVerlag, New York, NY, pp. 304-341.

Yagi, K., Tsuruta, H., Minami, K., 1997. Possible options for mitigating methane emission from rice cultivation. Nutr. Cycling Agroecosyst. 49, 213-220.

Yavitt, J.B., Williams, C.J., Wieder, R.K., 2000. Controls on microbial production of methane and carbon dioxide in three Sphagnum-dominated peatland ecosystems as revealed by a reciprocal field peat transplant experiment. Geomicrobiol. J. 17, 61-88.

Zoger, M., Engel, A., McKenna, D.S., Schiller, C., Schmidt, U., Woyke, T., 1999. Balloon-borne in situ measurements of stratospheric $\mathrm{H}_{2} \mathrm{O}, \mathrm{CH}_{4}$ and $\mathrm{H}_{2}$ at midlatitudes. J. Geophys. Res. 104, $1817-1825$. 